\title{
Evolution and functional characterization of pectate lyase PEL12, a member of a highly expanded Clonostachys rosea polysaccharide lyase 1 family
}

Lea Atanasova ${ }^{1,2,4^{*}}$ (D), Mukesh Dubey ${ }^{1}$, Marica Grujić ${ }^{2}$, Mikael Gudmundsson ${ }^{3}$, Cindy Lorenz ${ }^{4}$, Mats Sandgren ${ }^{3}$, Christian P. Kubicek ${ }^{2,5}$, Dan Funck Jensen ${ }^{1}$ and Magnus Karlsson ${ }^{1}$

\begin{abstract}
Background: Pectin is one of the major and most complex plant cell wall components that needs to be overcome by microorganisms as part of their strategies for plant invasion or nutrition. Microbial pectinolytic enzymes therefore play a significant role for plant-associated microorganisms and for the decomposition and recycling of plant organic matter. Recently, comparative studies revealed significant gene copy number expansion of the polysaccharide lyase 1 (PL1) pectin/pectate lyase gene family in the Clonostachys rosea genome, while only low numbers were found in Trichoderma species. Both of these fungal genera are widely known for their ability to parasitize and kill other fungi (mycoparasitism) and certain species are thus used for biocontrol of plant pathogenic fungi.

Results: In order to understand the role of the high number of pectin degrading enzymes in Clonostachys, we studied diversity and evolution of the PL1 gene family in C. rosea compared with other Sordariomycetes with varying nutritional life styles. Out of 17 members of $C$. rosea PL1, we could only detect two to be secreted at acidic pH. One of them, the pectate lyase pel12 gene was found to be strongly induced by pectin and, to a lower degree, by polygalacturonic acid. Heterologous expression of the PEL12 in a PL1-free background of T. reesei revealed direct enzymatic involvement of this protein in utilization of pectin at pH 5 without a requirement for $\mathrm{Ca}^{2+}$. The mutants showed increased utilization of pectin compounds, but did not increase biocontrol ability in detached leaf assay against the plant pathogen Botrytis cinerea compared to the wild type.
\end{abstract}

Conclusions: In this study, we aimed to gain insight into diversity and evolution of the PL1 gene family in C. rosea and other Sordariomycete species in relation to their nutritional modes. We show that C. rosea PL1 expansion does not correlate with its mycoparasitic nutritional mode and resembles those of strong plant pathogenic fungi. We further investigated regulation, specificity and function of the C. rosea PEL12 and show that this enzyme is directly involved in degradation of pectin and pectin-related compounds, but not in C. rosea biocontrol.

Keywords: Pectin, Clonostachys rosea, Trichoderma reesei, Phylogeny, Enzyme, Plant biomass degradation

\footnotetext{
* Correspondence: lea.atanasova@boku.ac.at

${ }^{1}$ Forest Mycology and Plant Pathology, Swedish University of Agricultural

Sciences, P.O. Box 7026, SE-75007 Uppsala, Sweden

${ }^{2}$ Research division of Biochemical Technology, Institute of Chemical,

Environmental and Biological Engineering, Vienna University of Technology,

Gumpendorferstrasse 1a, 1060 Vienna, Austria

Full list of author information is available at the end of the article
}

(c) The Author(s). 2018 Open Access This article is distributed under the terms of the Creative Commons Attribution 4.0 International License (http://creativecommons.org/licenses/by/4.0/) which permits unrestricted use, distribution, and reproduction in any medium, provided you give appropriate credit to the original author(s) and the source, provide a link to the Creative Commons license, and indicate if changes were made. The Creative Commons Public Domain Dedication waiver (http://creativecommons.org/publicdomain/zero/1.0/) applies to the data made available in this article, unless otherwise stated. 


\section{Background}

Pectin is a structural heteropolysaccharide present in the primary cell walls and in the middle lamella of terrestrial plants. The functions of pectin in cell walls are diverse and include plant growth and development, morphogenesis, defense, cell adhesion, cell wall structure, cellular expansion, porosity, ion binding, hydration of seeds, leaf abscission and fruit development, among others [1, 2]. In nature, pectic structures are extremely diverse, depending on the origin of the plant and on the plant tissue. Three pectic structural elements, homogalacturonan, rhamnogalacturonan-I and substituted galacturonans have been isolated from primary cell walls, are structurally characterized [3] and contain different degree of their main component, D-galacturonic acid. Substituted galacturonans are characterized by the presence of saccharide appendant residues branching from a backbone of D-galacturonic acid residues [4], whereas in rhamnogalacturonan $\mathrm{I}$, the galacturonic acid residues are partly substituted by $\alpha-1-2$ linked rhamnose residues. In addition, several side chains containing sugars, such as xylose, arabinose, glucose, fucose, mannose or galactose, have been found to be linked to the main backbone structure [5]. The galacturonic acid moieties in the backbone can also be esterified on the carboxylic acid moiety by methyl groups.

Polysaccharide lyases (PL) are a group of enzymes that cleave uronic acid-containing polysaccharide chains via a $\beta$-elimination mechanism to generate an unsaturated hexenuronic acid residue and a new reducing end [6]. The CAZy database (http://www.cazy.org; [7] has classified these enzymes to families and subfamilies to reflect their structural features and substrate specificities. The database currently comprises $21 \mathrm{PL}$ families, from which PL1, PL3 and PL9 contain fungal pectin/pectate lyases [8]. Based on the methylation degree of the homogalacturan backbone of pectin, pectin and pectate lyases either cleave methylated or demethylated regions of pectin, respectively. Both enzymes share a conserved structure in a parallel $\beta$-helix and are grouped together in polysaccharide lyase family 1 (PL1; EC 4.2.2.2, EC 4.2.2.9 and EC 4.2.2.10.) [7].

Pectate lyases cleave glycosidic linkages preferentially in polygalacturonic acid, forming an unsaturated product $(\Delta-4,5$-D-galacturonate) through a transelimination reaction. Contrary to pectin lyases they have an absolute requirement of $\mathrm{Ca}^{2+}$ ions and are classified as endo-pectate lyases (EC 4.2.2.2) that acts towards the substrate in a random way, and exo-pectate lyases (EC 4.2.2.9) that catalyze substrate cleavage from the non-reducing end [9]. Pectin lyases catalyze the random cleavage of pectin, preferentially highly esterified pectin, producing unsaturated methyloligogalacturonates [9]. The two types of lyases display essential differences in their active site, which is responsible for substrate binding and optimum $\mathrm{pH}$. Pectin lyases have optimal activity at $\mathrm{pH}$ around 5.5, whereas pectate lyases favor higher $\mathrm{pH}$ optima around 8.5 [10]. However, Pedolli et al. [9] showed that many fungal lyases have their optimal activity at acid and neutral $\mathrm{pH}$, while those from bacteria are more active at alkaline $\mathrm{pH}$. Nevertheless, it is still an enigma why pectate lyases are more active at a basic $\mathrm{pH}$ when the $\mathrm{pH}$ of the plant cell wall is acidic [11].

Microorganisms produce plant cell wall-degrading enzymes as part of their strategies for plant invasion or plant degradation. Pectic enzymes can cause plant tissue maceration, cell lysis and modification of the cell wall structure, allowing other depolymerasing enzymes to act on their respective substrates [12]. Pectic enzymes therefore play a crucial role in microbial plant biomass degradation. Several fungal pectin/pectate lyases from a variety of microbial species have been functionally characterized, such as the saprotrophic/opportunistic Aspergillus niger [13-16], A. oryzae [16, 17], Penicillium griseoroseum [18], P. occitanis [19], and the phytopathogenic fungi Glomerella cingulata [20] Colletotrichium gloeosporioides [21], C. lindemuthianum [22] and Botrytis cinerea [23]. Recently, comparative genome analysis of Clonostachys rosea (Hypocreales, Bionectriaceae) revealed that PL1 is one of the most significantly expanded gene families in this ubiquitous mycoparasitic fungus compared to nine closely related Sordariomycetes [24]. C. rosea is a filamentous fungus that colonizes living plants thereby activating induced resistance, competes with other fungi for space and nutrients in the soil and the rhizosphere and directly parasitizes on other fungi and nematodes, and is thus of interest as a biological control agent $[25,26]$. Taxonomically, C. rosea belongs to the same order (Hypocreales) but a different family (Bionectriaceae) than the more studied Trichoderma spp. mycoparasitic species (Hypocreaceae) [24]. In contrast to C. rosea, Trichoderma spp. have none or only few PL1 genes in their genomes (T. reesei and $T$. virens none, $T$. atroviride two genes), more similar to the saprotrophic Neurospora crassa [24].

In this study, we aimed to gain more insight into diversity and evolution of the PL1 gene family in C. rosea and other Sordariomycete species in relation to their nutritional modes. We investigated the evolution of PL1 enzymes in C. rosea using genome wide analysis of PL1 genes, and specificity and function of the pel12 gene coding for the only pectate lyase protein that is secreted in acidic pectic conditions.

\section{Results}

Genome wide analysis of polysaccharide lyases in C. rosea Sequence similarity and domain screening confirmed the presence of 17 PL1 family genes in the genome of $C$. 
rosea IK726. We named C. rosea PL1 genes and their according proteins pel1/PEL1 to pel17/PEL17 as listed in Table 1. The Cazy modules and subfamilies delimitation revealed that $C$. rosea PL1 contained four subfamilies; 2,
4, 7 and 9, while three genes could not be assigned to any subfamilies (Table 1 and Fig. 1). Out of seven genes from the PL1_4 subfamily, two were predicted to carry fungal-type CBM1 at the C-terminal, whereas the

Table $1 \mathrm{PL}$ genes in the C. rosea genome with assigned protein IDs, gene name, PL families, additional domains and subfamily identification, known activity based on Cazy database, list of crystal structures related to the PL families and organisms for which 3D structures are available in the PDB database

\begin{tabular}{|c|c|c|c|c|c|c|}
\hline C. rosea protein ID & $\begin{array}{l}\text { Gene } \\
\text { name }\end{array}$ & $\begin{array}{l}\text { CAZy module(s) } \\
\text { and subfamilies }\end{array}$ & Known Activities & $\begin{array}{l}\mathrm{PDB} / 3 \mathrm{D} \\
\text { structure } \\
\text { accession nr. }\end{array}$ & $\begin{array}{l}\text { 3D structure } \\
\text { status }\end{array}$ & $\begin{array}{l}\text { Organism with known } \\
\text { 3D structure }\end{array}$ \\
\hline \multicolumn{7}{|c|}{ PL1 genes identified in C. rosea } \\
\hline BN869_T00011408 & pel1 & PL1 & \multirow{17}{*}{$\begin{array}{l}\text { pectate lyase (EC 4.2.2.2); } \\
\text { exo-pectate lyase (EC 4.2.2.9); } \\
\text { pectin lyase (EC 4.2.2.10) }\end{array}$} & \multirow{17}{*}{$\begin{array}{l}1 / D J[A, B] 1 \mid D K[A] \\
1 \mathrm{QCX}[A] 1 \mathrm{PXZ}[\mathrm{A}, \mathrm{B}]\end{array}$} & \multirow[t]{17}{*}{ parallel $\beta$-helix } & \multirow{17}{*}{$\begin{array}{l}\text { Aspergillus niger, } \\
\text { Juniperus ashei }\end{array}$} \\
\hline BN869_T00008859 & pel2 & & & & & \\
\hline BN869_T00000002 & pel3 & CE8-PL1 & & & & \\
\hline BN869_T00000920 & pel4 & PL1_2 & & & & \\
\hline BN869_T00008472 & pel5 & \multirow[t]{5}{*}{ PL1_4 } & & & & \\
\hline BN869_T00010915 & pel6 & & & & & \\
\hline BN869_T00006080 & pel7 & & & & & \\
\hline BN869_T00010737 & pel8 & & & & & \\
\hline BN869_T00008735 & pel9 & & & & & \\
\hline BN869_T00007710 & pel10 & \multirow[t]{2}{*}{ PL1_4-CBM1 } & & & & \\
\hline BN869_T00005779 & pel11 & & & & & \\
\hline BN869_T00006915 & pel12 & \multirow[t]{5}{*}{ PL1_7 } & & & & \\
\hline BN869_T00007653 & pel13 & & & & & \\
\hline BN869_T00008627 & pel14 & & & & & \\
\hline BN869_T00002081 & pel15 & & & & & \\
\hline BN869_T00010228 & pel16 & & & & & \\
\hline BN869_T00007566 & pel17 & CBM1-PL1_9 & & & & \\
\hline \multicolumn{7}{|c|}{ Other PL gene families and PL subfamilies identified in C. rosea } \\
\hline \multicolumn{2}{|l|}{ BN869_T00011160 } & PL20 & $\begin{array}{l}\text { endo- } \beta-1,4-g \text { lucuronan } \\
\text { lyase } A(G \mid A)(E C \text { 4.2.2.14) }\end{array}$ & $2 Z Z][A]$ & $\begin{array}{l}\text { putative beta-jelly } \\
\text { roll fold }\end{array}$ & $\begin{array}{l}\text { Trichoderma reesei } \\
\text { NBRC } 31329\end{array}$ \\
\hline \multicolumn{2}{|l|}{ BN869_T00008392 } & \multirow[t]{10}{*}{ PL3_2 } & \multirow[t]{10}{*}{ pectate lyase (EC 4.2.2.2) } & \multirow{10}{*}{$\begin{array}{l}\text { 1EE6[A] 3B4N[A,B] } \\
\text { 3B8Y[A,B] 3B90[A,B] }\end{array}$} & \multirow[t]{10}{*}{ parallel $\beta$-helix } & \multirow{10}{*}{$\begin{array}{l}\text { Bacillus sp. KSM-P15, } \\
\text { Dickeya dadantii } 3937\end{array}$} \\
\hline BN869_T00003737 & & & & & & \\
\hline \multicolumn{2}{|l|}{ BN869_T00012955 } & & & & & \\
\hline \multicolumn{2}{|l|}{ BN869_T00007220 } & & & & & \\
\hline \multicolumn{2}{|l|}{ BN869_T00010913 } & & & & & \\
\hline \multicolumn{2}{|l|}{ BN869_T00013332 } & & & & & \\
\hline \multicolumn{2}{|l|}{ BN869_T00000798 } & & & & & \\
\hline \multicolumn{2}{|l|}{ BN869_T00011510 } & & & & & \\
\hline \multicolumn{2}{|l|}{ BN869_T00010121 } & & & & & \\
\hline \multicolumn{2}{|l|}{ BN869_T00013099 } & & & & & \\
\hline \multirow{2}{*}{\multicolumn{2}{|c|}{$\begin{array}{l}\text { BN869_T00002494 } \\
\text { BN869_T00003115 }\end{array}$}} & \multirow[t]{2}{*}{ PL4_1 } & \multirow{3}{*}{$\begin{array}{l}\text { rhamnogalacturonan } \\
\text { lyase (EC 4.2.2.23) }\end{array}$} & \multirow{3}{*}{$\begin{array}{l}\text { 1NKG[A] 2XHN[A,B] } \\
3 \mathrm{NJV}[\mathrm{A}] 3 \mathrm{NJX}[\mathrm{A}]\end{array}$} & $\beta$-sandwich and & Aspergillus aculeatus KSM 510 \\
\hline & & & & & & \\
\hline BN869_T00009470 & & PL4_3 & & & & \\
\hline BN869_T00000818 & & PL9_3 & $\begin{array}{l}\text { pectate lyase (EC 4.2.2.2); } \\
\text { exopolygalacturonate lyase } \\
\text { (EC 4.2.2.9); thiopeptidoglycan } \\
\text { lyase (EC 4.2.2.-) }\end{array}$ & $1 R \cup 4[A]$ & parallel $\beta$-helix & Dickeya dadantii 3937 \\
\hline
\end{tabular}




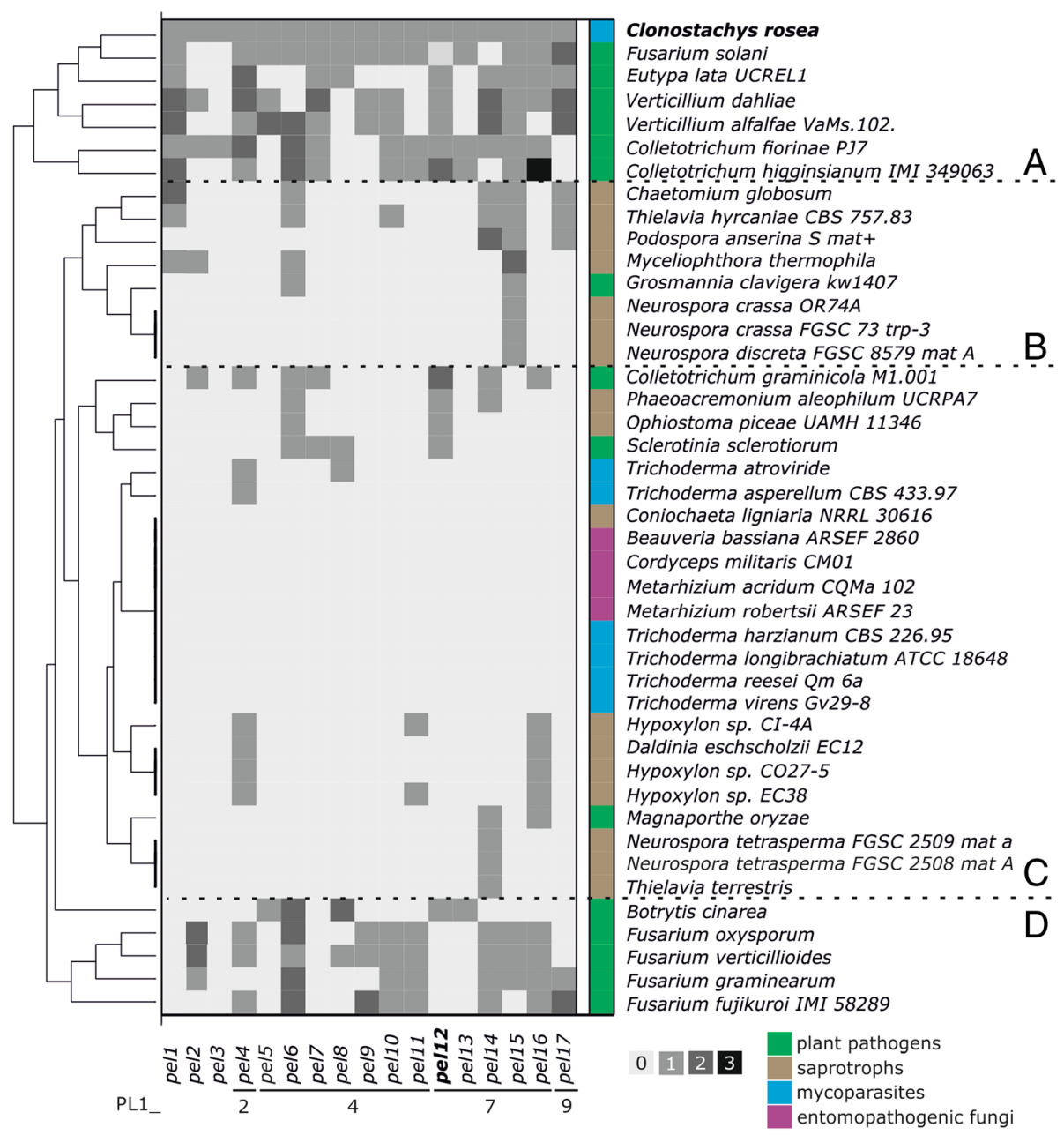

Fig. 1 Hierarchical clustering based on PL1 gene content in Sordariomycetes and Botrytis cinerea and Sclerotinia sclerotiorum (Leotiomycetes). The clusters are marked with letters A to D. The squares colored with four different shades of gray represent the number of C. rosea orthologs per species. The color annotation on the right marks the nutritional mode of fungi

predicted PEL17 sequence from the PL1_9 subfamily contained a CBM1 at the N-terminal. Besides the PL1 domain, PEL3 was predicted to contain a pectinesterase domain (pfam01095) belonging to the CE8 pectin methylesterases (EC 3.1.1.11) family. As for the other PL families, ten PL3 genes (pectate lyases), three PL4 genes (rhamnogalacturonan lyases), and one gene each of PL20 and PL9 were further identified in C. rosea.

Mining of the available Sordariomycetes genomes together with plant pathogenic Leotiomycetes $B$. cinerea and S. sclerotiorum revealed striking differences between the number of PL1 genes (Additional file 1: Table S2). From 213 genes sorted in 17 groups resembling C. rosea orthologs, pel5, pel8, pel9 and pel11 (PL1_4), pel13 (PL1_7) and pel3 had less than 10 orthologs in 42 species, whereas most PL1 genes in Sordariomycetes were found to be orthologs of C. rosea pel6 (25 genes). Pel3 orthologs were only found in C. rosea and C. fiorinae. Out of 43 genomes characterized, nine did not possess any PL1 genes at all. These represented some species of Hypocreales that parasitize on or kill other fungi (mycoparasites), such as species of the genus Trichoderma or those that feed on insects (entomopathogens), such as Beauveria bassiana, Cordyceps militaris, and Metarhizium spp. (Fig. 1, cluster C). Hierarchical clustering of the genes showed that expansions and contractions of the PL1 families in fungi might be evolutionary driven as taxonomically similar taxa contain similar blocks of orthologs, however the number of genes belonging to PL1 also strongly depended on the nutritional mode of the fungi. Species with very limited number of PL1 genes were found among saprotrophic Xylariales (Daldinia and Hypoxylon spp.) as well as in Sordariales; in the genus Neurospora, Podospora and Thielavia terrestris (Fig. 1, cluster B), whereas among the most 
expanded were, with an exception of of mycoparasitic $C$. rosea, plant pathogens of the order Glomerellales (Verticillium and Glomerella/Colletotrichum species), and hypocreaceous Fusarium solani (Nectria haematococca) (Fig. 1, cluster A). Interestingly, the rice blast pathogen Magnaporthe oryzae has a very small number of PL1 genes (only two genes), and the leotiomycetous plant pathogens $S$. sclerotiorum and B. cinerea have only four and seven genes belonging to PL1, respectively. Apart of $N$. haematococca, the plant pathogenic Fusaria (Hypocreales) comprised between nine and 11 PL1 orthologs (Fig. 1, cluster D), and clustered separately from other plant pathogens, all lacking orthologs of pel1, pel5, pel7, pel12 and pel13. Among the currently published and up to date Sordariomycetes genome, $C$. rosea is the species with the highest PL1 gene number (17 genes).

\section{Acidic pectin conditions induce the secretion of $C$. rosea polygalacturonases, polysacharide lyases and arabinofuranosidases}

We screened for $C$. rosea proteins secreted in acidic minimal medium ( $\mathrm{pH} 5$ ) containing $0.5 \%$ polygalacturonic acid and apple pectin, respectively. As a control, protein expression on glucose and sucrose was monitored. Abundant secretion of protein could be observed on pectin, however not on glucose and sucrose. A single clearly visible SDS-PAGE band at ca. $37 \mathrm{kDa}$ was detected. Replicate samples were submitted for peptide mapping analysis using tandem mass spectroscopy (MS).
The MS analysis detected a total 18 proteins with high confidence levels associated with the peptide sequence found and did not contain shared peptides (Table 2). Redundant proteins were automatically grouped and are not shown. The highest scoring protein was annotated as an endopolygalacturonase from the GH28 family. Two additional endopolygalacturonases from the same family were detected in the set. Furthermore, glucoamylase from GH15, two alpha-L-arabinofuranosidases from GH54, two PL1 pectin lyases and a $\beta$-fructosidase from GH34 were identified (Table 2). An unclassified exopolygalacturonase, a pectinesterase, a FAD (Flavin Adenine Dinucleotide)-dependent oxygenase and a series of peptidases were also secreted under the given conditions.

Out of a total of 17 genes classified as PL1 and putatively involved in degradation of pectin, only two members were secreted during the cultivation of $C$. rosea in an acidic pectin medium, PEL6 and PEL12, respectively. These two proteins belong to subfamily 4 and 7 of PL1, respectively, and their theoretical molecular weight was estimated to be around 39 and $35 \mathrm{kDa}$, respectively. Interestingly, the pel6 orthologs were found in most analyzed genomes (in 25 out of 43). Pel12 orthologs were present in only 13 Sordariomycete species, in most plant pathogenic fungi and several saprotrophs with contracted PL1 families, but not in M. oryzae or in any Fusarium species, not even in $N$. haematococca with its highly expanded PL1 gene content (Fig. 1).

Table 2 List of C. rosea proteins secreted on 0.5\% pectin minimal medium in acidic condition ( $\mathrm{pH}$ 4) obtained by tandem mass spectrometry. The protein score represents the sum of the scores of the individual peptides found in each replicate, whereas the coverage [in \%] annotates the sequence covered by identified peptides. Number of distinct peptide sequences found in the protein group, sequence length (AAs), the calculated molecular weight (MW) and isoelectric point (pl) of the protein and putative annotation are listed. Members of PL1 are marked gray

\begin{tabular}{|c|c|c|c|c|c|c|c|c|c|}
\hline C. rosea protein ID & \multicolumn{2}{|c|}{$\begin{array}{l}\text { Score and } \\
\text { coverage I }\end{array}$} & \multicolumn{2}{|c|}{$\begin{array}{l}\text { Score and } \\
\text { coverage I }\end{array}$} & \multirow{2}{*}{$\begin{array}{l}\begin{array}{l}\text { No. of } \\
\text { peptides }\end{array} \\
8\end{array}$} & \multirow{2}{*}{$\begin{array}{l}\text { AAs } \\
377\end{array}$} & \multirow{2}{*}{$\begin{array}{l}\begin{array}{l}\text { MW } \\
{[\mathbf{k D a}]}\end{array} \\
37.9\end{array}$} & \multirow{2}{*}{$\begin{array}{r}\mathbf{p I} \\
6.96\end{array}$} & \multirow{2}{*}{$\begin{array}{l}\text { Putative annotation } \\
\mathrm{GH} 28 \text {, endopolygalacturonase }\end{array}$} \\
\hline BN869_T00000016 & 572.79 & 21.49 & 1080.27 & 20.42 & & & & & \\
\hline BN869_T00010712 & 53.07 & 29.20 & 55.42 & 32.43 & 11 & 589 & 63.0 & 5.62 & GH15, glucoamylase \\
\hline BN869_T00010915 & 28.51 & 30.95 & 29.23 & 29.37 & 8 & 378 & 38.8 & 8.00 & PL1, pectin lyase (pel6) \\
\hline BN869_T00010084 & 17.22 & 10.54 & 44.55 & 32.01 & 5 & 503 & 51.8 & 5.96 & GH54, alpha-L-arabinofuranosidase \\
\hline BN869_T00009301 & 15.52 & 10.33 & 16.16 & 12.87 & 4 & 513 & 56.4 & 5.94 & FAD-dependent oxidoreductase \\
\hline BN869_T00008124 & 12.02 & 15.60 & 4.95 & 7.24 & 4 & 359 & 37.0 & 8.59 & GH28, endopolygalacturonase \\
\hline BN869_T00010670 & 9.96 & 9.87 & 19.14 & 15.79 & 3 & 456 & 50.3 & 4.83 & Exopolygalacturonase \\
\hline BN869_T00007584 & 8.56 & 13.25 & na & na & 3 & 332 & 34.6 & 7.40 & Hypothetical protein \\
\hline BN869_T00007127 & 7.64 & 10.67 & 9.09 & 13.41 & 3 & 328 & 34.8 & 8.63 & Pectinesterase \\
\hline BN869_T00006915 & na & na & 12.51 & 9.31 & 2 & 333 & 35.2 & 6.52 & PL1, pectin lyase B (pel12) \\
\hline BN869_T00012141 & 7.15 & 10.95 & 9.61 & 10.95 & 2 & 274 & 28.7 & 4.73 & Peptidase \\
\hline BN869_T00010699 & 6.54 & 2.95 & 9.81 & 2.95 & 2 & 882 & 96.3 & 6.02 & Conserved hypothetical protein \\
\hline BN869_T00011374 & 5.44 & 5.38 & na & na & 2 & 483 & 52.8 & 4.93 & Carboxypeptidase \\
\hline BN869_T00010745 & 5.18 & 4.55 & 8.61 & 7.13 & 2 & 505 & 52.4 & 4.84 & GH54, alpha-L-arabinofuranosidase \\
\hline BN869_T00011200 & 10.80 & 6.18 & 16.05 & 9.76 & 2 & 615 & 67.6 & 5.87 & Tripeptidyl-peptidase \\
\hline BN869_T00010351 & 4.63 & 4.37 & 11.20 & 8.75 & 2 & 526 & 57.7 & 4.56 & GH32, beta-fructosidase \\
\hline BN869_T00007140 & na & na & 6.55 & 17.19 & 2 & 221 & 23.2 & 4.91 & Hypothetical protein \\
\hline BN869_T00008124 & na & na & 4.95 & 7.24 & 2 & 359 & 37.0 & 8.59 & GH28 endopolygalacturonase \\
\hline
\end{tabular}


Phylogenetic analysis reveals a C. rosea pel12 gene paralog and a putatively new PL1 subfamily

Phylogenetic analysis of the PL1 protein family containing 41 Sordariomycete genomes, Leotiomycetes $B$. cinerea and S. sclerotiorum and A. niger (Eurotiomycetes) as an outgroup, revealed a clear separation of pectin and pectate lyase enzymes. Among pectate lyases, six supported clades were found, and based on sequence similarity with structurally characterized proteins [7] four of these clades were identified as PL1 subfamilies 2, 7, 9 and 10 (Fig. 2). Based on the well characterized A. niger PlyA protein $[27,28]$ the largest group was identified as subfamily 7 , where six C. rosea PL1 paralogs were found. Interestingly, plyA was the only detected pectate lyase from $A$. niger and S. sclerotiorum. In contrast, Hypocrealean and Glomerellalean species contain many PL1_7 members and C. rosea PL1 proteins were overrepresented in this subfamily (PEL12 PEL16). In addition, the $C$. rosea PL1_7 pectate lyase PEL12, secreted on pectin in acidic conditions (see above) and PEL13 revealed to be close protein paralogs (Fig. 2). The closest neighbors of these two C. rosea paralogs were Glomerellales pectate lyases, with the sister branch of orthologs from Fusarium spp. (Hypocreales). Moreover, PL1_9 and PL1_10 subfamilies contained proteins from Glomerellalean and Hypocrealean species, although PL1_10 also contained some members of Sordariales and at the basal position a member of Xylariales (Fig. 2). Furthermore, for two other pectate lyase clades, no sequence similarity to any so far characterized PL1 subfamily could be found. One of them includes the PEL1 pectate lyase and might, due to the statistical support of the clade, represent a putatively new subfamily among PL1.

The second large supported group represent pectin lyases, all part of PL1 subfamily 4. The analysis revealed many small supported subclades of which seven contained $C$. rosea members. Three of these groups included members of $A$. niger pectin lyases: PelF, PelC/E and PelA/B/D. Furthermore, $S$. sclerotiorum and B. cinerea (Leotiomycetes) PL1s were forming separated clades, but not at the basal position as evolutionary expected. Using the proteins of these species as outgroups, we speculate that the split of PL1 family in subgroups is likely older then subphilum Pezizomycotina.

Together with $C$. rosea, $T$. atroviride and T. asperellum were the only mycoparasites with PL1 proteins. The pectate lyase singlets of the latter two species grouped at the basal position in one of the putatively new PL1 subgroups. Pectin lyase from $T$. atroviride, however, was shown to be closely related to PelE from $A$. niger and $B$. cinerea (Fig. 2).

\section{Structural and regulatory divergences in C. rosea likely} led to functional differentiation of PEL12 and its paralogs The phylogenetic analysis of PL1 proteins revealed that $C$. rosea PEL12 and its close paralogue PEL13 were members of the pectate lyase PL1_7 subfamily, together with orthologs from plant pathogenic fungi with highly expended PL1 families such as Verticillium and Colletotrichum (Glomerella) (Fig. 2). An alignment of PL1_7 protein sequences was further analyzed to identify divergent amino acid sites and regions that may indicate functional differentiation between PL1_7 members (Additional file 2: Figure S1). Reverse Conservation Analysis (RCA) was applied to reveal conserved and variable regions between the PEL12/PEL13 clade and the closely related PEL2 clade. Five regions were identified that displayed signs of functional divergence; high variation in one clade in combination with low variation in the other clade (Fig. 3a). Regions I and V contained the $\mathrm{N}$ - and $\mathrm{C}$-terminal flanks of the main $\beta$-helix structure, respectively. Regions II, III and IV were shorter and comprise loops in the central $\beta$-sheet core. Homologous structures and homology modelling suggested that the linear pectin polymer substrate of PL1 enzymes likely binds along one face of the $\beta$-helix axis. The active site where the enzymatic $\beta$-elimination cleavage of galacturonate occurs is located between the catalytic base (putatively arginine Arg225 in PEL12) and two $\mathrm{Ca}^{2+}$ ions (Fig. 3b). The pentagalacturonate ligand and the two putative calcium ions were extracted from a homologous Bacillus subtilis pectate lyase crystal structure (PDB:ID 3KRG) to visualize functional areas. Regions III and IV were located close to the active site but on the opposite face from the binding cleft of the $\beta$-helix.

PEL12 and its paralog PEL13 shared $78 \%$ of identity on the amino acid level, but contrary to PEL12, PEL13 was not detected among the proteins secreted on apple pectin at $\mathrm{pH} 4$ (Table 2). Gene expression analysis of pel12 and pel13 on $0.5 \%$ glucose, sucrose, pectin and polygalacturonic acid revealed major differences in their transcriptional responses. Expression of pel12 was strongly induced on apple pectin and polygalacturonic acid whereas its paralog was transcribed but not differentially regulated in these conditions (Fig. 4). The protein sequence alignment showed several mutational shifts from non-charged amino acids in PEL12 to positively charged lysine in the paralog, mostly located in regions I, II and V (Fig. 4) that displayed signs of functional divergence between the PEL12/PEL13 and PEL2 clades. Particularly, regions I and II were located in the substrate entry/exit areas where differences in charge distribution might impact substrate selectivity [29].

Furthermore, the promoter sequences ( $1 \mathrm{~kb}$ upstream of the start codon) of pel12 and pel13 displayed major differences in their nucleotide sequences. Analyses with the JASPAR CORE fungi tool [30] showed that HAP2 binding sites were commonly present in both promoter regions. HAP2 acts as a component of the CCAT-binding factor, a transcriptional activator that binds to the upstream activation site (UAS2) of the CYC1 gene and other genes 


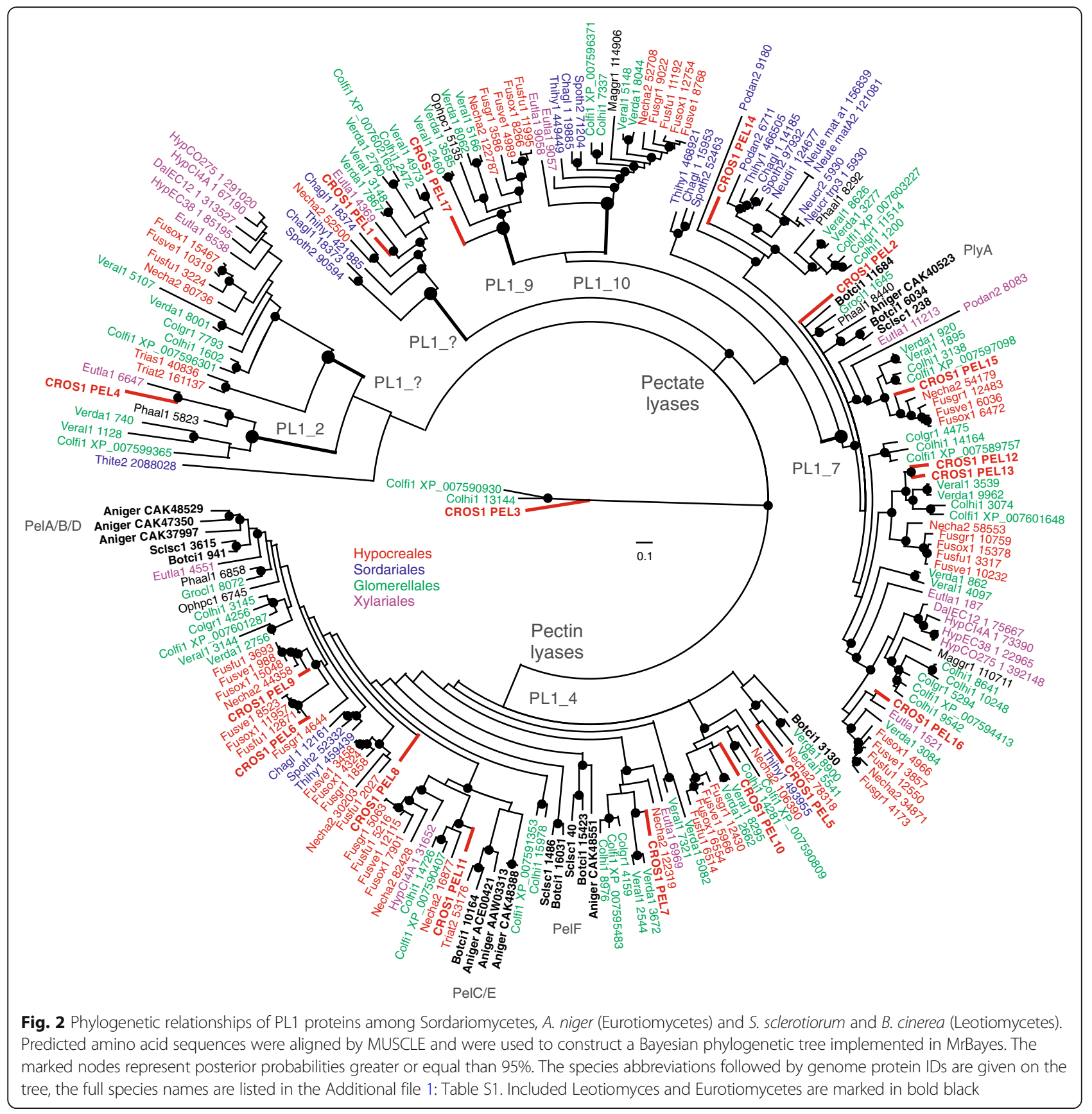

involved in mitochondrial electron transport and activate their expression in Saccharomyces cerevisiae. In contrast, putative binding sites for $\mathrm{pH}$-response transcription factor pacC/RIM101, activator of stress genes ASG1, regulatory protein CAT8, transcription factor PDR8; transcription factor MBP1, regulatory protein SWI6 and regulator of drug sensitivity RDS1 were only found in the pel12 promoter, whereas Ty transcription activator TEC1, pre-rRNA-processing protein FHL1 and arginine metabolism regulation protein ARGR1 binding sites were only detected in the pel13 promoter.
PEL12 induces utilization of pectin-related compounds in

\section{T. reesei pel120E mutants}

The PEL12 protein was overexpressed in T. reesei QM 9414 (WT) under the constitutive enolase promoter and Cel7a terminator. The gene integration into T. reesei genome was verified by the pel12 overexpression primers (Additional file 1: Table S2). As mentioned above, the expression of $C$. rosea PEL12 was detected as a $37 \mathrm{kDa}$ band on a SDS-PAGE gel. The overexpressed PEL12 protein was detected at the correct size in T. reesei pel12OE-1 and pel12OE-2 mutants but not in the 

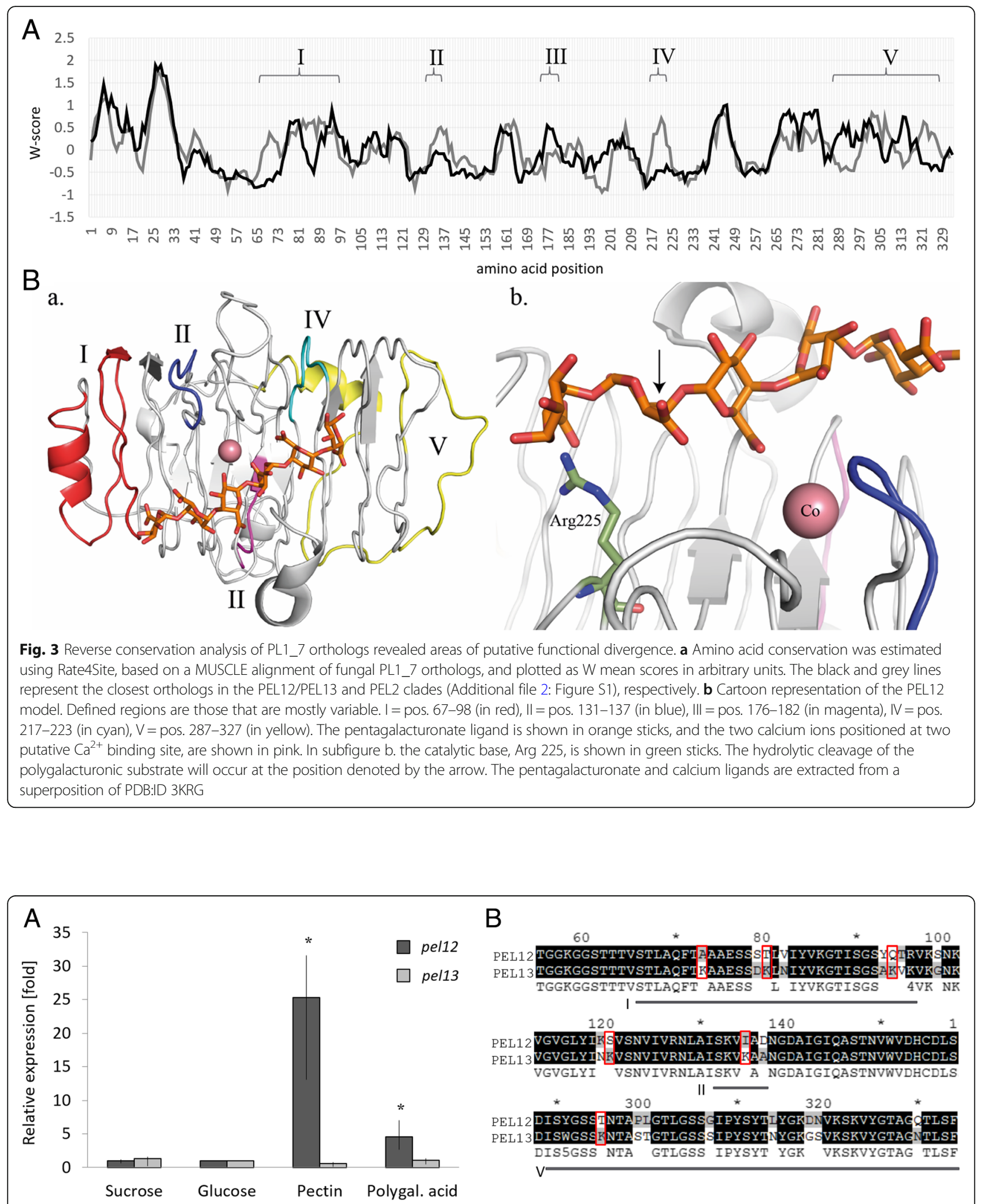

B

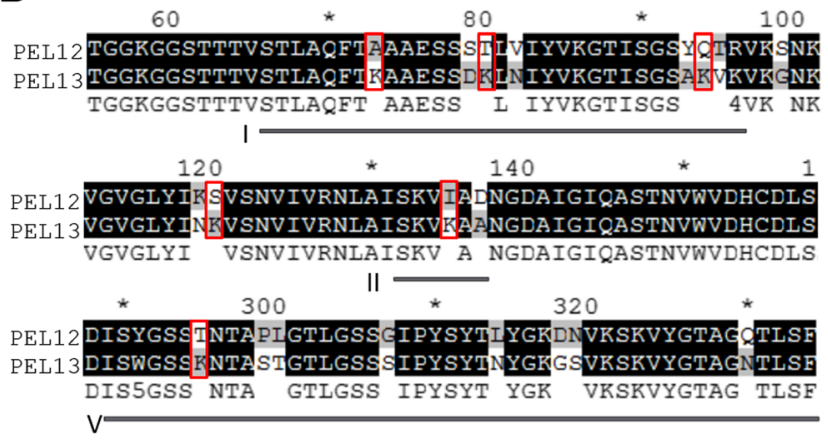

Fig. 4 a Differential gene expression of the pel12 (BN869_T0006915) and pel13 (BN869_T00007653) genes in C. rosea, induced by 0.5\% sucrose, glucose, pectin or polygalacturonic acid. Asterisks indicate significantly $(P \leq 0.05)$ higher expression compared with the glucose control treatment. b Mutational shifts from non-charged amino acids to positively charged lysine (red squares) in the PEL12 and PEL13 protein sequences. Roman numbers mark the evolutionary variable regions I, II and V detected between the closest paralogs (see Fig. 3). Asterisks mark next ten amino acids 
WT culture filtrates after $48 \mathrm{~h}$ of cultivation on $1 \%$ glucose (Additional file 2: Figure S2). Gene expression analysis confirmed a constitutive expression of pel12 in $T$. reesei on inducing and repressing carbon sources (data not shown). The mutants exhibited significantly better growth on pectin medium and improved utilization of pectin compounds such as galacturonic acid, arabinose and rhamnose compared to the WT in the BIOLOG Phenotypic assay developed for filamentous fungi (Fig. 5). Growth rates on glucose, glycerol, galactose, fructose, and N-acetyl-D-glucosamine (NAG) were not altered. Indeed, several authors have proposed the existence of a regulatory system that activates the expression of a group of pectinolytic genes in response to galacturonic acid, and activates other pectinolytic genes in response to L-arabinose, L-rhamnose, ferulic acid and D-xylose $[27,31,32]$. Interestingly, it became evident that $T$. reesei utilizes galacturonic acid at a very low level (after water, at position 91 out of 95 carbon sources tested, see Additional file 2: Figure S3). In contrast, in the pel12OE mutants it was ranked among the first half of the best assimilated carbon sources (position 45). Xylitol, a sugar alcohol found in low concentrations in the fibers of many fruits and vegetables, was shown to be the best utilized carbon source by pel12OE mutants, and it elevated the growth of these strains much more than any of the best utilized compounds tested for the T. reesei WT (Additional file 2: Figure S3).

Enzymatic activity of heterologously expressed PEL12 was measured using the standard pectate and pectin lyase activity assay as described by Collmer et al. [12] Concentrated crude protein extracts from $T$. reesei WT and pel12OE mutants were added to the substrates containing either polygalacturonic acid and $\mathrm{CaCl}_{2}$, or apple pectin, both at $\mathrm{pH} 8.5$ and $\mathrm{pH} 5$. The pel12OE-2 mutant supernatant yielded a linear activity of $0.02 \mu \mathrm{M} \mathrm{min}^{-1} \mathrm{~mL}^{-1}$ in first $10 \mathrm{~min}$ in the pectin substrate at $\mathrm{pH} 5$, but not at $\mathrm{pH} 8.5$ or in polygalacuronic acid. The WT and the pel12OE-1 mutant supernatants did not show any catalytic activity in any of repeated assays.

After cultivation of the strains on $1 \%$ apple pectin for $72 \mathrm{~h}$, the presence of monosaccharides arabinose, glucose, galactose, fructose, and rhamnose as well as galacturonic acid in the T. reesei WT and the pel12OE-2 fermentation broths were quantified. Analysis was done by high-performance anion-exchange chromatography with pulsed amperometric gold electrode detection (HPAEC-PAD) paired with an anion exchange CarboPac PA1 column. Rhamnose was not released by either strain. In contrast, large differences in the ability to release arabinose, galactose and glucose were detected between the T. reesei WT and the pel12OE- 2 mutant. The fermentation broth of pel12OE-2 contained around $15 \mathrm{mg} \mathrm{L}^{-1}$ less glucose and also less fructose compared to the wild type, whereas arabinose and galactose were more abundant in the pel12OE-2 supernatant (Fig. 6). Furthermore, galacturonic acid content in the WT and the pel12OE-2 culture broths was very similar (Fig. 6). The occurrence of several peaks right before the galacturonic acid at a retention time of 22.5 to 25 min might indicate the presence of 4,5-unsaturated products released by the pectate/pectin cleavage of polygalacturonan usually detectable with the pectate/pectin assay at $232 \mathrm{~nm}$. The pel12OE-2 mutant indeed showed an increase of these products in the culture filtrate compared to the WT.

\section{Deletion or overexpression of pel12 does not affect the biocontrol potential of $C$. rosea or $T$. reesei}

To determine the function of PEL12 we deleted the pel12 gene from the C. rosea genome. Successful gene replacement in mitotically stable transformants was confirmed by PCR as described in our previous studies [33, 34]. Amplification of an expected size of PCR fragment in putative transformants, while no amplification in WT validated the successful deletion of pel12 (Additional file 2: Figure S4A). Furthermore, RT-PCR experiments using primers specific to the pel12 sequence demonstrated the complete loss of pel12 transcript in each mutant (Additional file 2: Figure S4B). The deletion did not lead to any morphological differences in the mutants compared to the WT strain. Furthermore, the pel12 deletion in $C$. rosea did not influence utilization of pectin compounds as tested with BIOLOG Phenotypic assay (Additional file 2: Figure S5). The biocontrol potential of $C$. rosea WT, C. rosea $\Delta$ pel12 mutants, $T$. reesei WT and $T$. reesei pel12OE mutants against $B$. cinerea was evaluated using a detached $A$. thaliana leaf assay. All tested strains significantly reduced the lesion size caused by $B$. cinerea, but no quantitative or qualitative difference between the WT strains and their corresponding pel12 mutants were detected (Additional file 2: Figure S6).

\section{Discussion}

Despite the fact that $C$. rosea and Trichoderma spp. belong to different families (Bionectriaceae and Hypocreaceae, respectively) within the order Hypocreales, they share many commonalities in their lifestyle as rhizosphere-competent saprotrophs and necrotrophic mycoparasites. Because of these features, certain species of these genera are used as biological control agents in agricultural and horticultural crop production. However, recent comparative genomic studies of C. rosea and Trichoderma spp. [24, 35-37] revealed distinct differences in gene family evolution, indicative of fundamental differences in the life strategies of these fungi [38] with direct bearing for the implementation of biocontrol in agriculture. Karlsson et al. [24] identified the PL1 gene family to evolve under selection for 

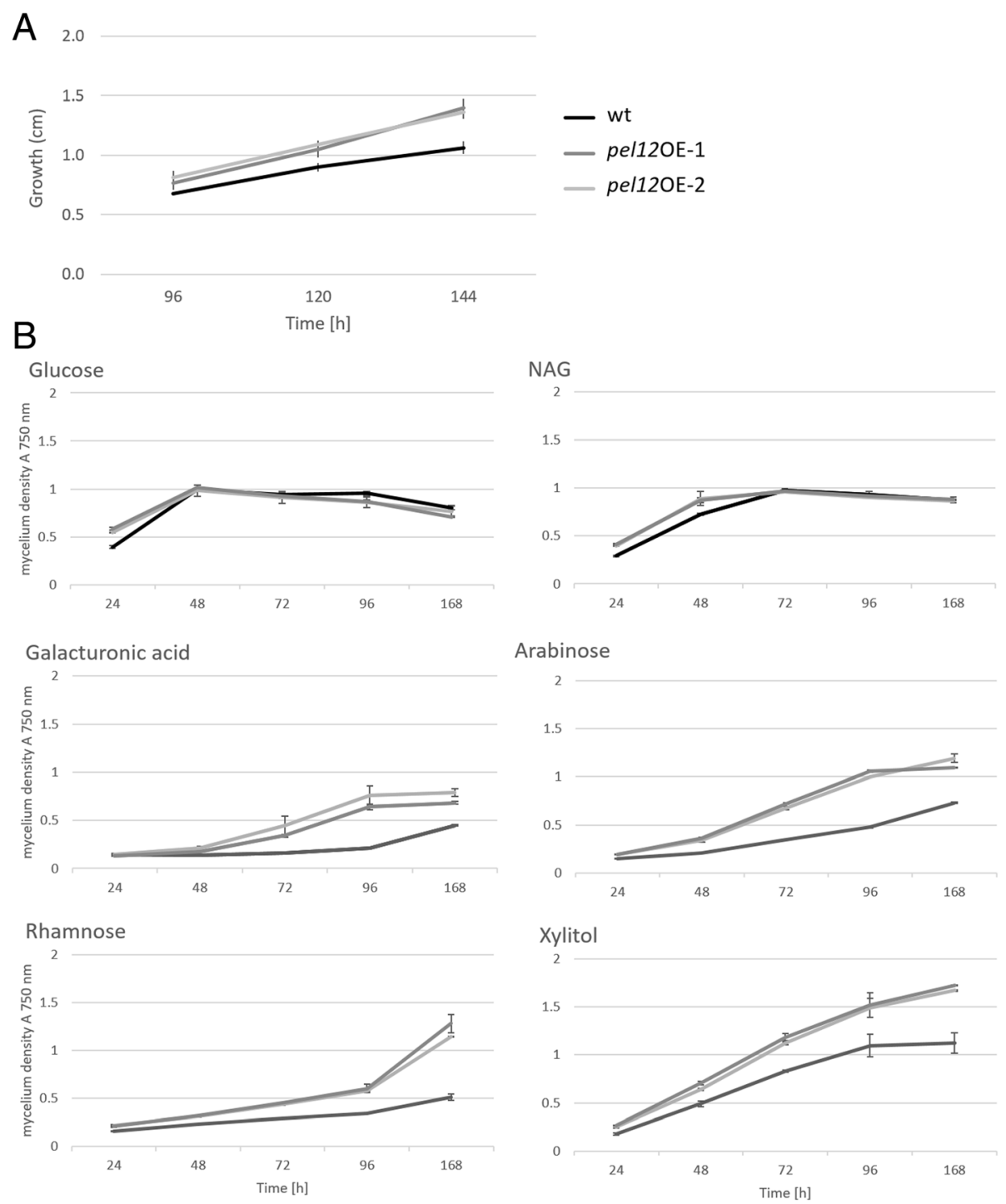

Fig. 5 Utilization of carbon sources in T. reesei QM 9414 and pel12OE mutants. a Growth of strains on 1\% agarose supplemented with $2 \%$ pectin. b Growth rates of strains on selected carbon sources assessed by BIOLOG Phenotypic assay for filamentous fungi. The cultures were incubated at $28^{\circ} \mathrm{C}$ in darkness

increasing gene copy number in C. rosea, but not in Trichoderma spp., which prompted us to perform a more detailed investigation of these genes in C. rosea.

Analysis and hierarchical clustering of gene numbers in a set of different fungal genomes revealed a clear distinction of PL1 gene distribution related to nutritional mode; Trichoderma mycoparasites and entomopathogenic fungi have none or drastically reduced PL1 gene numbers, while PL1 gene numbers in plant pathogenic fungi such as $N$. haematococca, Colletotrichum and Verticillium are highly expanded. Plant pathogenic fungi use plant cell wall-degrading enzymes for penetration and nutrient acquisition, while plants have evolved strategies that allow them to detect and to defend against the attack of pathogens by producing inhibitors of these enzymes [22]. Pectic structures are also extremely diverse, depending on the plant and plant tissue. We can therefore speculate that the observed expansion of PL1 pectin/pectate lyase numbers in several plant pathogenic fungi is driven by selection for functional diversification with regard to regulation and substrate specificity. Our phylogenetic analysis of the PL1 gene family does not contradict this hypothesis, as we detected a high number of hierarchically organized subgroups and divisions, including two previously unknown PL1 subgroups, which may represent isozymes with particular properties. For example, significant differences between two fungal races of $C$. lindemuthianum were detected in terms of the expression of the Clpnl2 gene encoding for pectin lyase 2, where the pathogenic race 1472 responded faster and 


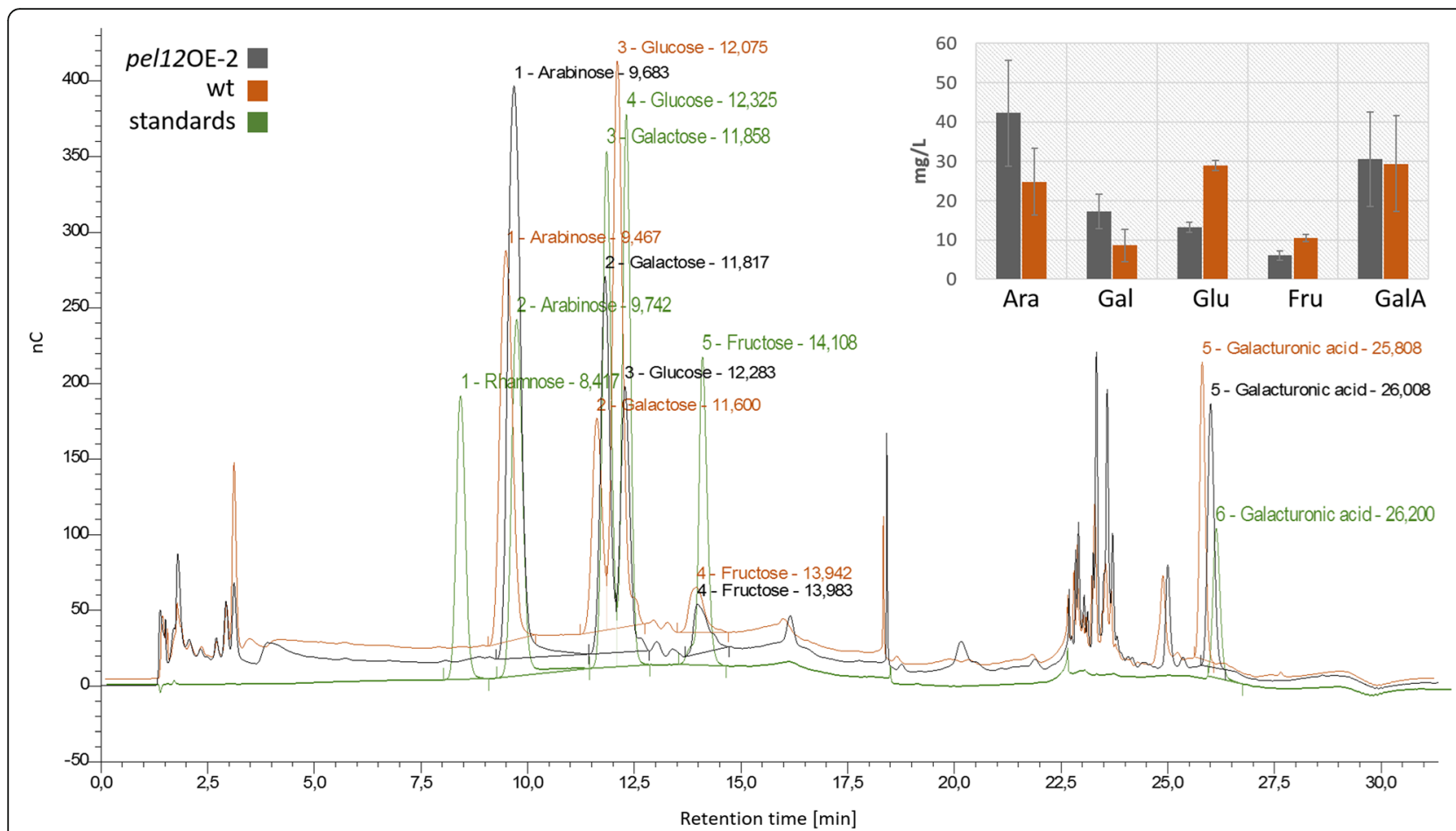

Fig. 6 HPAEC-PAD analysis of T. reesei QM 9414 and the pel12OE-2 mutant supernatants collected after $72 \mathrm{~h}$ post inoculation on minimal medium supplemented with $1 \%$ apple pectin, pH 5. The bars represent the detected quantity of monosaccharides arabinose (Ara), galactose (Gal), glucose (Glu), fructose (Fru), and galacturonic acid (GalA) in the culture extracts. nC is the unit of electric charge measured in nano-Coulomb, meaning the charge transported by a constant current of one Ampere in one second

with higher expression levels than the non-pathogenic race 0 [22]. Wijesundra et al. [39] reported that $C$. lindemuthianum race $\beta$ secreted two forms of pectin lyase, having pI values of 8.2 and 9.7, respectively, when grown in culture with sodium polypectate or isolated Phaseolus vulgaris hypocotyl cell walls as the main carbon source. All the forms of pectin lyases showed maximum activity under alkaline conditions [39]. Furthermore, in $C$. gloeosporioides, a pectin/pectate lyase gene was considered important for infection of avocado fruit [40] and two pectin lyase genes, pnl-1 and pnl-2, which encode for extracellular enzymes that differ both in their expression in pure culture and during infection, were isolated from C. gloeosporioides f. sp. malvae [21]. Expression of an exogenous pectinase in a pathogenic fungus may be sufficient to change the pathogenicity and the host: $C$. magna, a pathogen of cucurbits, was transformed with a pectate lyase gene from the avocado pathogen C. gloesporioides and became more aggressive on watermelon and avocado [40]. In contrast, expression of an endopolygalacturonase gene from Fusarium oxysporum f. sp. Iycopersici in strains of $F$. oxysporum $\mathrm{f}$. sp. melonis did not induce any change in pathogenicity [41].

However, C. rosea is not a plant pathogenic fungus and hence the selective advantages for high numbers of PL1 genes in this species should be different from plant pathogenic fungi. C. rosea is reported to intimately interact with plants through root surface colonization $[24,42]$ and by penetrating epidermal cells [43]. This intimate interaction with plants can result in plant growth promotion [44] and induction of defense reactions in both wheat and tomato [44, 45], but it is difficult to argue how this superficial level of plant interaction can justify the existence of 17 PL1 genes in C. rosea. An alternative explanation is that PL1 pectin/pectate lyases are involved in saprotrophic utilization of plant organic matter in soil. It has been shown previously that germination and activity of $C$. rosea in soil depends on the presence of organic matter or root exudates [46]. It is plausible that degradation of pectic compounds in soil contributes to the versatile capacity of $C$. rosea to establish in soil and the rhizosphere.

The induction of several pectin-degrading enzymes, including the two different PL1 proteins PEL6 and PEL12, during growth on apple pectin shows that $C$. rosea indeed has the capacity to utilize pectin as a nutrient source. The phylogenetic analysis shows that PEL6 is a pectin lyase while PEL12 is a pectate lyase, suggesting their synergistic action during pectin degradation [27]. A closer inspection of the PL1 phylogenetic tree reveals an overrepresentation of PL1 genes from C. rosea and several plant pathogenic species in subgroup PL1_7, which 
include the secreted PEL12 pectate lyase. If the expansion of the PL1_7 subgroup is driven by selection for functional diversification, we would expect structural and regulatory differences between the C. rosea PL1_7 paralogs. An indication of differential regulation between PEL12 and its close paralog, PEL13, come from the fact that PEL12, but not PEL13, was detected in the culture broth of $C$. rosea grown on apple pectin. This was further confirmed at the transcriptional level as pel12, but not pel13, was induced by pectin and polygalacturonic acid. Instead, pel13 was constitutively expressed during the investigated conditions showing that it is not a pseudogene. Substantial differences in the promoter regions of pel12 and pel13 provided an explanation for the differential expression. The presence of a putative binding motif for the $\mathrm{pH}$-response transcription factor $\mathrm{PacC}$ in the pel12 promoter is particularly interesting, as disruption of the $p a c C$ gene in C. rosea results in attenuated virulence against nematodes [47]. The serine protease gene $\operatorname{prC}$ in C. rosea also carry an inverted PacC binding motif in its promoter, and gene disruption of $\operatorname{prC}$ also results in attenuated virulence against nematodes $[47,48]$, thereby establishing a link between $\mathrm{pH}$-responsiveness and nematode virulence in C. rosea. We also found indications of non-random structural changes between PL1_7 paralogs, localized in the predicted substrate entry/exit areas of the enzymes. Based on the homology modelling of the $\beta$-helix structure covering the main body of PEL12 with the carbohydrate binding site, we speculate that the variation between the PL1_7 paralogs results in charge-distribution alternations that may influence the affinity for methylated or non-methylated galacturonate, consequently leading to functional divergence.

Functional diversification of other carbohydrate-active enzymes has sometimes resulted in new biochemical functions or even loss of catalytic activity. For example, some chitinases have lost their catalytic activity but retained their chitin-binding capacity, resulting in lectin- or receptor-like proteins [49-51]. However, our data suggest that this is not the case with PEL12 in C. rosea, but rather that it constitutes an active pectate lyase. First, the homology modelling predicts the enzymatic $\beta$-elimination cleavage active site of PEL12 to occur between a catalytic arginine (Arg230) and a bound $\mathrm{Ca}^{2+}$ metal ligand, which is in accordance with the three-dimensional structures of five members of the pectate lyase superfamily: Erwinia chrysanthemi pectate lyase C (PELC) [52] and pectate lyase E (PELE) [53], Bacillus subtilis pectate lyase [54] and A. niger pectin lyase A (PLA) [10] and pectin lyase B (PLB) [55]. Secondly, overexpression of pel12 in a PL1-free T. reesei background results in increased utilization of pectin and pectin-related carbon sources of the $T$. reesei pel12OE mutants, providing indirect evidence for pectinolytic activity of PEL12. Thirdly, detection of pectin/pectate lyase enzymatic activity in the supernatant, increased ability to release arabinose and galactose, and the presence of 4,5-unsaturated degradation products during growth on pectin by one of the $T$. reesei pel12OE mutants further support the conclusion that PEL12 is an active, pectinolytic enzyme.

Deletion of the pel12 gene in C. rosea indicated that PEL12 is dispensable for growth on PDA and biocontrol of $B$. cinerea on A. thaliana leaves. It is possible that the remaining 16 PL1 genes, and the additional 15 pectinolytic genes (one GH20, 10 PL3, three PL4 and one PL9) that we detected in the $C$. rosea genome are responsible for masking an effect, but the lack of effect on biocontrol in $T$. reesei OE mutants indicates that PEL12 indeed has no role in the interaction of these mycoparasitic species and their fungal prey.

\section{Conclusions}

In summary, we show that high numbers of PL1 genes are present in many plant pathogenic fungi, and the mycoparasite C. rosea. Specifically subgroup PL1_7 pectate lyases contain many C. rosea paralogs, and we provide indications for functional diversification between these paralogs. One member, pel12, encodes a functional pectinolytic enzyme that is induced by pectin and polygalacturonic acid, but is dispensable for biocontrol.

\section{Methods}

\section{Strains and growth conditions used in this study}

$C$. rosea strain IK726 and mutants derived from it, and $B$. cinerea strain B05.10 were maintained on potato dextrose agar (PDA) medium (Difco, Germany) at $25{ }^{\circ} \mathrm{C}$. T. reesei strain QM9414 and mutants derived from it were cultivated on PDA or PDA supplemented with $100 \mathrm{ng} / \mu \mathrm{L}$ hygromycin B (Sigma, Sweden), respectively, at $28^{\circ} \mathrm{C}$. For all assays on solid media, inoculation was performed by transferring a $5 \mathrm{~mm}$ diameter agar plug of actively growing mycelium to the center of the Petri dish. Minimal liquid media $(\mathrm{pH} 4)$ supplemented with $0.5 \%(w / v)$ apple pectin (70-75\% esterification; Sigma, Sweden), polygalacturonic acid sodium salt (Serva, Germany), sucrose or glucose prepared essentially as described by Shah et al. [23] were used for $C$. rosea and $T$. reesei biomass determination, enzyme activity assays and gene expression analysis unless otherwise specified. Biomass and fermentation broths were sampled after $72 \mathrm{~h}$ of cultivation at $200 \mathrm{rpm}$ and $25{ }^{\circ} \mathrm{C}$. T. reesei mutants were cultivated in liquid Mandels-Andreotti medium containing $5 \mathrm{~g} / \mathrm{L} \quad \mathrm{KH}_{2} \mathrm{PO}_{4}$, $1.4 \mathrm{~g} / \mathrm{L}\left(\mathrm{NH}_{4}\right)_{2} \mathrm{SO}_{4}, 0.3 \mathrm{~g} / \mathrm{L}$ Urea, $0.3 \mathrm{~g} / \mathrm{L} \mathrm{MgSO}_{4} \times 7 \mathrm{H}_{2} \mathrm{O}$, $0.3 \mathrm{~g} / \mathrm{L} \mathrm{CaCl}, 20 \mathrm{~mL} / \mathrm{L}$ trace elements $\left(250 \mathrm{mg} / \mathrm{L} \mathrm{FeSO}_{4}\right.$ x $7 \mathrm{H}_{2} \mathrm{O}, 85 \mathrm{mg} / \mathrm{mL} \mathrm{MnSO}_{4} \times \mathrm{H}_{2} \mathrm{O}, 70 \mathrm{mg} / \mathrm{mL} \mathrm{ZnSO}_{4} \mathrm{x}$ $\left.7 \mathrm{H} 2 \mathrm{O}, 100 \mathrm{mg} / \mathrm{mL} \mathrm{CoCl} \mathrm{Cl}_{2} \times 2 \mathrm{H}_{2} \mathrm{O}\right), 2 \mathrm{~g} / \mathrm{L}$ peptone from casein, $2 \mathrm{~g} / \mathrm{L}$ Tween 20 supplemented with $1 \%$ of carbon 
source (glucose or apple pectin), $\mathrm{pH}$ adjusted to 5 . For inoculation of liquid media, conidia were harvested from 7 days old Petri dishes in physiological solution with $0.025 \%$ of Tween 20 , and $300 \mu \mathrm{L}$ conidial suspension $\left(2.5 \times 10^{8}\right.$ conidia/mL) were added into $125 \mathrm{~mL}$ of medium.

\section{Genome wide screening for PL1 homologues in C. rosea and Sordariomycetes}

PL1 homologous proteins from 41 Sordariomycete species, B. cinerea and S. sclerotiorum (Leotiomycetes) (Additional file 1: Table S1) were identified by iterative BLAST approach and retrieved from the JGI DOE MycoCosm (http://genome.jgi.doe.gov) and NCBI (https://www.ncbi. nlm.nih.gov/genome/) genomic resource on 9th February 2015. The C. rosea protein sequences were trimmed for carbohydrate-binding module family 1 (CBM1) and carbohydrate esterases (CE) domains prior to BLAST analysis. The sequences with E-values higher than $1 \times 10^{-8}$ were not considered for the analysis. Conserved protein domains were predicted using NCBI Conserved Domain (CD) search [56], InterPro [57] and ExPASy ScanProsite [58] databases. The PL1 data set was unified and aligned using online multiple sequence alignment tool Clustal Omega [59]. Hierarchical clustering analysis of PL1 gene homologues in Sordariomycete and Leotiomycete species were performed using Statistica program (version 6.1; StatSoft Inc., Tulsa, OK) under complete linkage using Euclidean distances.

\section{Phylogenetic and protein sequence analyses}

Predicted amino acid sequences were aligned by MUSCLE analysis tool [60] and were trimmed for the variable $\mathrm{N}$ and C-terminal regions (signal peptide, CBM and CE domains). Phylogenetic analyses were performed using MrBayes v3.2.6 [61] using maximum parsimony optimality criterion and Bayesian inference of phylogeny, respectively. The Dayhoff amino acid substitution model was applied for Bayesian analysis and Metropolis-coupled Markov chain Monte Carlo (MCMCMC) sampling was performed with two simultaneous runs of four incrementally heated chains performed for 10 million generations. Trees were summarized after burning first $25 \%$ of the trees. Two completely independent analyses starting from different random trees were carried out. Bayesian posterior probabilities (PP) were obtained from the 50\% majority-rule consensus of trees sampled every 100 generations after removing the first trees. PP values lower than 0.95 were not considered significant.

Regions of low amino acid conservation in PL1 protein alignments were identified by reverse conservation analysis (RCA), as described by Lee [62]. In short, Rate4Site (Version 2.01) was used to calculate the degree of conservation (S score, high scores correspond to low degree of conservation) for each amino acid position using the empirical Bayesian method [63, 64]. A sliding-window average $(n=7)$ of normalized S scores (mean was 0 and standard deviation was 1) was plotted in Excel (Microsoft) (W mean score) and significant peaks were defined by intensity (I) values of 0.5 [62].

\section{PEL12 homology modeling}

A C. rosea PEL12 homology model was constructed by the I-TASSER server located at http://zhanglab.ccmb.med. umich.edu [65], with a C-score of -0.45 , an estimated TM score of $0.66+-0.13$ and an estimated Root-Mean-Square Deviation (RMSD) of $7.4+-4.3 \AA$ A. I-TASSER utilizes a suite of predictive and modelling techniques like threading of the query sequence onto the closest known homologous protein crystal structures. The PEL12 model showed closest structural similarity, TM-score 0.89 and RMSD of 1.79 , with the PL1 structure from Acidovorax avenue subsp. citrulli (PDB:ID 4HWV), a bacterial fruit and plant pathogen [29]. Figures and analysis were performed using the PyMOL Molecular Graphics System (Version 1.8 Schrödinger, LLC.) and pectin substrate and metal ligands were extracted from PDB:ID 3KRG [66].

\section{Deletion of the pel12 gene in C. rosea}

Multisite Gateway cloning system was used to generate the deletion construct as described previously [33, 34]. C. rosea pel12 deletion mutants were generated by replacing pel12 with the hygB selection cassette by homologous recombination using Agrobacterium tumefaciens-mediated transformation (ATMT) protocol for C. rosea [67]. Homologous integration of the deletion cassette in putative transformants was validated using a PCR screening approach as described in our previous work $[33,34]$ with primers located within the hygB cassette (Hyg F/Hyg R) together with primers located upstream $(6915 \mathrm{KO} F)$ and downstream (6915 KO R) of the construct (Additional file 1: Table S2). RT-PCR analysis was conducted on WT and deletion strains using RevertAid premium reverse transcriptase (Fermentas, St. Leon-Rot, Germany) and primer pairs specific for pel12 to confirm the complete loss of pel12 transcript in mutant strains.

\section{Heterologous expression of $C$. rosea PEL12 in $T$. reesei} Genomic DNA of $C$. rosea was isolated using a hexadecyltrimethylammonium bromide (CTAB)-based method [68]. Primers containing PacI and Xbal restriction sites were designed to target the $5^{\prime}$ and $3^{\prime}$ sides of the pel12 gene (Additional file 1: Table S2). The pel12 gene was amplified using Phusion DNA polymerase (Finnzymes, Vantaa, Finland) under the following conditions: initial denaturation for $60 \mathrm{~s}$ at $98{ }^{\circ} \mathrm{C}$ followed by 32 cycles of denaturation $\left(10 \mathrm{~s}\right.$ at $\left.98{ }^{\circ} \mathrm{C}\right)$, annealing $\left(30 \mathrm{~s}\right.$ at $\left.60{ }^{\circ} \mathrm{C}\right)$ and extension $\left(72{ }^{\circ} \mathrm{C}\right.$ for $\left.20 \mathrm{~s}\right)$. Final extension was performed 
for $5 \mathrm{~min}$ at $72{ }^{\circ} \mathrm{C}$. The amplified fragment was then ligated with the pCR2.1-TOPO vector (Invitrogen) and the plasmid was transformed into One Shot TOP10 Escherichia coli competent cells using TOPO TA Cloning Kit (Invitrogen) according to manufacturer protocol. After the plasmid purification, pel12 was restricted out of the TOP10 pel12 plasmid using EcoRI and was digested by $\mathrm{XbaI}$ and PacI restriction enzymes (Fermentas). The pTreno_CBH1 vector [69], containing an enolase promoter, the $T$. reesei $c b h 1$ gene and $c b h 2$ terminator followed by the $h p h$ hygromycin resistance cassette, was also digested at the PacI and Xbal restriction sites and the cbh1 gene was replaced by pel12 using T4 DNA ligase kit (USB, Affymetrix). The construct was amplified in E. coli and extracted using the Promega Midi Prep Kit (Sweden). The obtained plasmid was linearized with SbfI and transformed in electrocompetent $T$. reesei QM9414 spores following the electroporation protocol essentially as described by Linger et al. [69]. Hygromycin-resistant pel12OE transformants were checked for mitotic stability by several rounds of cultivations. Genomic DNA was extracted from T. reesei using the Qiagen DNeasy Plant Mini Kit following the manufacturer protocol. A PCR and quantitative PCR (qPCR) screening approach was performed to validate the integration of the pTreno_Trpel12 in transformants using $6915 \mathrm{fwOE} 2 / 6915 \mathrm{revOE} 2$ primers as well as 6915_qPCR_fw2/6915_qPCR_rev2. T. reesei QM9414 and plasmid DNA were used as negative and positive controls, respectively.

\section{Protein detection and enzyme assays}

C. rosea and T. reesei proteins secreted on $0.5 \%$ apple pectin, polygalacturonic acid, glucose or sucrose liquid medium ([23]; see above) were on-column concentrated using Vibraspin membrane columns with $10 \mathrm{kDa}$ cut-off (Sartorius Stedim). For the protein separation on the SDS-PAGE gel, Laemmli sample buffer premixed with $\beta$-mercaptoethanol (9:1) was added to each sample in biological duplicates), mixed and denaturated for $3 \mathrm{~min}$ at $99^{\circ} \mathrm{C}$ and applied to $4-20 \%$ pre-casted Mini Protein TGX stain-free SDS-PAGE gels (BioRad). The gels were stained using undiluted AcquaStain solution (Bulldog Bio). Distinct bands were excised, the proteins were reduced, alkylated and in-gel digested with trypsin according to a standard operating protocol. Thereafter, the samples were dried and resolved in $15 \mu \mathrm{l} 0.1 \%$ formic acid. Peptides were separated in reversed-phase on a C18-column and electrosprayed on-line to Q Exactive Plus mass spectrometer (Thermo Finnigan). Tandem mass spectrometry (MS) was performed applying Higher-energy collisional dissociation (HCD) at the MS Facility, SciLifeLab, Uppsala University, Sweden. The database searches were performed using the Sequest algorithm embedded in Proteome
Discoverer 1.4 (Thermo Fisher Scientific) towards predicted $C$. rosea protein models. The search criteria for protein identification were set to at least two matching peptides of $95 \%$ confidence level per protein.

Liquid state fermentations of T. reesei QM9414 and the pel12OE mutants were performed on minimal MandelsAnderotti medium (see above). Fermentation was carried out in $500 \mathrm{~mL}$ Erlenmeyer flask in darkness at $28{ }^{\circ} \mathrm{C}$, $220 \mathrm{rpm}$ for $72 \mathrm{~h}$. Samples were taken after 24, 48 and 72 h. Protein detection was performed using SDS-PAGE electrophoresis essentially as described above.

A standard pectate lyase kinetic assay was performed using culture filtrates from $T$. reesei WT and pel12OE mutants' fermentations on $1 \%$ glucose essentially as described by Collmer et al. [12] with $0.24 \%(w / v)$ polygalacturonic acid mixed with $60 \mathrm{mM}$ Tris- $\mathrm{HCl}$ and $0.6 \mathrm{mM} \mathrm{CaCl}_{2}, \mathrm{pH} 8.5$ as substrate solution. $1 \mathrm{~mL}$ of crude supernatant was concentrated using Vivaspin columns with $10 \mathrm{kDa}$ cutoff of polyethersulfan membrane (Sartorius, Germany) in a final volume of $100 \mu \mathrm{L}$. The fermentation broths of the mutants were further tested for pectin lyase activity using the same protocol by replacing polygalaturonic acid with apple pectin and omitting $\mathrm{CaCl}_{2}$. All enzyme activity assays were performed at $\mathrm{pH} 5$ and 8.5. One unit of enzyme forms $1 \mu \mathrm{mol}$ of 4,5-unsaturated product in $1 \mathrm{~min}$ under the conditions of the assay. The molar extinction coefficient for the unsaturated product at $232 \mathrm{~nm}$ is $4600 \mathrm{M}^{-1} \mathrm{~cm}^{-1}$.

Assays with monosaccharides were conducted using $200 \mu \mathrm{L}$ of $T$. reesei $\mathrm{WT}$ and pel12OE mutant culture filtrates grown for $72 \mathrm{~h}$ on $1 \%$ apple pectin as described above. The proteins were heat-inactivated at $90{ }^{\circ} \mathrm{C}$ for $15 \mathrm{~min}$ and separated by centrifugation. Arabinose, glucose, galactose, fructose, galacturonic acid and rhamnose in the supernatants were quantified by high-performance anion-exchange chromatography with pulsed amperometric gold electrode detection (HPAEC-PAD) paired with an anion exchange CarboPac PA1 column $(4 \times 250 \mathrm{~mm}$ plus $4 \times 50 \mathrm{~mm}$ guard column) at $30{ }^{\circ} \mathrm{C}$ and $1 \mathrm{~mL} \mathrm{~min}^{-1}$ flow rate. The initial mobile phase of $18 \mathrm{mM} \mathrm{NaOH}$ was held for $7 \mathrm{~min}$; then a gradient from $18 \mathrm{mM}$ to $119 \mathrm{mM} \mathrm{NaOH}$ mixed with $18 \mathrm{mM} \mathrm{NaAc}$ was applied for $11 \mathrm{~min}$ followed by a gradient to $100 \mathrm{mM} \mathrm{NaOH}$ mixed with $150 \mathrm{mM}$ $\mathrm{NaAc}$ for $3 \mathrm{~min}$. This concentration was held for $2.5 \mathrm{~min}$ followed by fast gradient to $200 \mathrm{mM} \mathrm{NaOH}$ which was maintained for further $3 \mathrm{~min}$. Finally, $18 \mathrm{mM} \mathrm{NaOH}$ was applied for $15 \mathrm{~min}$ to equilibrate the columns for the next sample $(20 \mu$ injection volume). Ppm (parts per million) correspond to $\mathrm{mg} / \mathrm{l}$ of the substrate detected.

\section{Phenotype microarrays}

Growth rates on different carbon sources, except on apple pectin, were analyzed in biological duplicates using a phenotype microarray system for filamentous fungi 
(Biolog Inc., Hayward, CA), as described by Atanasova and Druzhinina [70]. Briefly, strains were cultivated on PDA for 7 days. Conidial inocula were prepared by rolling a sterile, wetted cotton swab over sporulating areas of the plates. The conidia were then suspended in sterile Biolog FF inoculating fluid $(0.25 \%$ Phytagel, $0.03 \%$ Tween 40), gently mixed, and adjusted to a transmission of $75 \%$ at $590 \mathrm{~nm}$ (using a Biolog standard turbidimeter calibrated to the Biolog standard for filamentous fungi). A total of $90 \mu \mathrm{L}$ of the conidial suspension was dispensed into each of the wells of the Biolog FF microplates (Biolog Inc.), which were incubated at $28{ }^{\circ} \mathrm{C}$ in darkness. The optical density (OD) at $750 \mathrm{~nm}$ (for detection of mycelial growth) was measured after 24, 48, 72, 96 and $120 \mathrm{~h}$ using a microplate reader (Biolog Inc.). Statistical analyses were performed using the Statistica software package (version 6.1; StatSoft Inc., Tulsa, OK). Growth rates on pectin were determined by cultivation of the fungi on solid Mandels-Anderotti minimal medium supplemented with $2 \%$ agarose and $1 \%$ apple pectin. The growth of mycelia was measured every $24 \mathrm{~h}$.

\section{Detached leaf bioassay}

A detached leaf assay for biocontrol of the grey mold pathogen B. cinerea was performed as described previously [33, 34]. In brief, leaves of 3-week-old Arabidopsis thaliana ecotype Colombia-0 (Col-0) plants, grown in a Percival growth chamber (CLF plant climates, $\mathrm{GmbH}$, Germany) with growth conditions described before [71], were detached from plants and placed on water agar plate with the petiole inserted in the agar. A $5 \mu$ d droplet of conidial suspension $\left(1 \times 10^{6}\right.$ conidia/mL) of $C$. rosea WT, C. rosea $\Delta$ pel12 mutants, $T$. reesei WT and T. reesei pel12OE mutants were inoculated on the adaxial surface of the leaf, dried for $30 \mathrm{~min}$ and re-inoculated with equal conidial concentration of $B$. cinerea at the same place. Plates were kept in Percival growth chambers and high humidity was maintained by sealing the plates with parafilm. The diameter of necrotic lesions was measured post $56 \mathrm{~h}$ of inoculation under the microscope using a DeltaPix camera and software (DeltaPix, Denmark). Bioassay experiments were performed in 4 biological replicates and each replicate consisted of six leaves for each treatment. The experiment was repeated two times.

\section{Transcriptional profiling by reverse transcription qPCR}

For gene expression analysis of C. rosea PL1 genes in different nutritional conditions (described above), mycelia were cultivated in liquid cultures as described by Shah et al. [23] and harvested $72 \mathrm{~h}$ post inoculation. For validation of pel12 heterologous expression, T. reesei WT and pel12OE mutants were cultivated on minimal Mandels-Andreotti medium supplemented with $1 \%$ glucose or apple pectin (see above) for $48 \mathrm{~h}$. Harvested biomass was immediately frozen in liquid nitrogen and stored at $-80{ }^{\circ} \mathrm{C}$. RNA extraction from all samples was done using the Qiagen RNeasy kit following the manufacturer's protocol (Qiagen, Hilden, Germany). RNA was treated with RNase-free DNaseI (Fermentas, St. Leon-Rot, Germany) and concentrations were determined using NanoDrop (Thermo Scientific, Wilmington, $\mathrm{DE})$. One microgram of total RNA was reverse transcribed in a total volume of $20 \mu \mathrm{l}$ using the iScript ${ }^{\text {th }}$ cDNA synthesis kit (BioRad, Germany). Transcript levels were quantified by qPCR using the EvaGreen qPCR Master Mix (Biotium) in an iQ5 qPCR System (Bio-Rad, Hercules, CA) using $98{ }^{\circ} \mathrm{C}$ for 2 min for initial denaturation and 40 cycles of $98{ }^{\circ} \mathrm{C}$ for $5 \mathrm{~s}, 58{ }^{\circ} \mathrm{C}$ for $10 \mathrm{~s}$ and $65{ }^{\circ} \mathrm{C}$ for $10 \mathrm{~s}$. Melt curve analysis was performed after the $\mathrm{qPCR}$ reactions, to confirm that the signal was the result from a single product amplification. Relative expression levels for target genes in relation to actin expression [72, 73] were calculated from the Ct (cycle threshold) values and the primer amplification efficiencies by using the formula described by Pfaffl [74]. Gene expression analysis was carried out in three biological replicates, each based on three technical replicates. Primer sequences used for gene expression analysis are given in the Additional file 1: Table S2.

\section{Additional files}

Additional file 1: Table S1. PL1 genes in to date available Sordariomycetes genomes together with plant pathogenic Leotiomycetes Botrytis cinerea and Sclerotinia sclerotiorum. For the presentation reasons the orthologues from Sordariomycetes, $B$. cinerea and S. sclerotiorum are assigned to one of the $17 \mathrm{C}$. rosea PL1 genes based on the highest E-value. Genome references: [24, 35, 36, 75-101]. Table S2. PCR and qPCR primers used in this study. PE annotate primer efficiency. attB and attBr site sequences are shown in lowercase. (XLSX $19 \mathrm{~kb}$ )

Additional file 2: Figure S1. Partial protein alignment of the closest neighbors of PEL12 and separation of the group A and B for further reverse conservation analysis. C. rosea paralogs BN869_T0006915 (PEL12) and BN869_T00007653 (PEL13) align to the group B, whereas the protein BN869_T0008859 (PEL2), Fusaria and some members of Sordariales are separated by several hallmarks forming the group A. Figure S2. SDS-PAGE gel showing the putative expression of the PEL12 protein (arrows) at $37 \mathrm{kDa}$ in the fermentation broths of two independent $T$. reesei PEL12 overexpression strains pel12OE-1 and pel12OE-2. The strains were cultivated for $48 \mathrm{~h}$ in MandelsAnderotti medium supplemented with $1 \%$ glucose. Figure S3. Carbon source utilization of $T$. reesei WT and pel12OE mutants on 95 different carbon sources based on BIOLOG Phenotypic assay for filamentous fungi. Mycelial density is shown for $96 \mathrm{~h}$ of incubation at $28^{\circ} \mathrm{C}$ in darkness. Black, gray and white circles represent mycelial density of T. reesei QM9414 (wt) and the mutants pel12OE-1 and -2 , respectively. Figure $\mathbf{S 4}$. Validation of pel12 mutant strains using PCR and RT-PCR. A: PCR verification of $\triangle$ pel12 using primers located within the hygB cassette (Hyg F /Hyg R) in combination with primers located upstream and downstream regions from the deletion cassette (6915 ko F / 6915 ko R). A PCR product of $\sim 2.5 \mathrm{~kb}$ using primers $6915 \mathrm{ko} \mathrm{F} / \mathrm{Hyg}$ R and $6915 \mathrm{ko}$ R / Hyg F were expected from a correct gene replacement. $M$, gene ruler DNA ladder mix; 1-3, independent $\Delta$ pel12 mutants; 4, WT strain. B: RT-PCR analysis of pel12 gene expression in WT and deletion strains using pel12 specific primers. A PCR product of $92 \mathrm{bp}$ was expected from the WT. M, gene ruler DNA ladder mix; 1 , WT; $2-4$, independent deletion strains. Primer combinations used for PCR and 
RT-PCR are given above the images. Figure S5. Carbon source utilization of $C$ rosea WT and $\Delta$ pel12 mutants ( $\triangle$ pel12 KOA, KOB, KOC) on 95 different carbon sources based on BIOLOG Phenotypic assay for filamentous fungi. Mycelial density is shown for $144 \mathrm{~h}$ of incubation at $28^{\circ} \mathrm{C}$ in darkness. Figure $\mathbf{S 6}$. Measurement of $B$. cinerea necrotic lesions area on detached leaves of Arabidopsis thaliana. The leaves were inoculated with C. rosea strains (A) or T. reesei (B) strains spores $30 \mathrm{~min}$ before application of $B$. cinerea spores. Necrotic lesion area was measured under the microscope using a DeltaPix camera and software $56 \mathrm{~h}$ post inoculations. Only B. cinerea inoculated leaves were used as control. Error bars represent standard deviation based on three biological replicates. Different letters indicate statistically significant differences $(P \leq 0.05)$ based on the Fisher test. (PDF $633 \mathrm{~kb}$ )

\section{Abbreviations}

$\left(\mathrm{NH}_{4}\right)_{2} \mathrm{SO}_{4}$ : ammonium sulfate; ATMT: Agrobacterium tumefaciens-mediated transformation; BLAST: Basic Local Alignment Search Tool; $\mathrm{Ca}^{2+}$ : calcium ion $\mathrm{CaCl}_{2}$ : calcium chloride; CAZy: Carbohydrate-Active enZYmes; CBM: CarbohydrateBinding Module; CD: Conserved Domain; CE: Carbohydrate Esterases; $\mathrm{CoCl}_{2}$ : cobalt(II) chloride; Ct: Cycle threshold; $C \mathrm{CAB}$ : hexadecyltrimethylammonium bromide; DNA: deoxyribonucleic acid; $\mathrm{FeSO}_{4}$ : iron(II) sulfate; $\mathrm{H}_{2} \mathrm{O}$ : water; HCD: Higher-energy Collisional Dissociation; HPAEC-PAD: High-Performance Anion-Exchange Chromatography with Pulsed Amperometric gold electrode; JGl DOE: Joint Genome Institute of the United States Department of Energy; $\mathrm{KH}_{2} \mathrm{PO}_{4}$ : monopotassium phosphate; MCMCMC: Metropolis-coupled Markov chain Monte Carlo; $\mathrm{MgSO}_{4}$ : magnesium sulfate; $\mathrm{MnSO}_{4}$ : manganese(II) sulfate; MS: Mass Spectrometry; NaAc: sodium acetate; $\mathrm{NaOH}$ : sodium hydroxide; NCBI: National Center for Biotechnology Information; OD: Optical Density; OE: overexpression; PCR: Polymerase Chain Reaction; pel: pectate lyase gene; PEL: pectate lyase protein; pel12OE: pel12 overexpression mutants; PL: Polysaccharide Lyase; Ppm: Parts per million; RCA: Reverse Conservation Analysis; RMSD: Root-MeanSquare Deviation of atomic positions; RNA: Ribonucleic acid; RT-PCR: Reverse Transcription PCR; SDS-PAGE: Sodium Dodecyl Sulfate Polyacrylamide Gel Electrophoresis; Tris-HCl: Trisaminomethane hydrochloride; WT: Wild Type; $\mathrm{ZnSO}_{4}$ : zinc sulfate; $\Delta$ pel12: pel12 deletion mutants

\section{Acknowledgements}

The authors are thankful to Dr. Daniel Kracher from the Institute of Food Technology, University of Natural Resources and Life Sciences, Vienna, Austria for his valuable comments and help with protein assays.

\section{Funding}

The funding body had no role in the design of the study or collection, analysis, and interpretation of data or in writing the manuscript. Financial support from the Carl Trygger Foundation for Scientific Research (grant number CTS 12:233 to MK), Swedish Research Council for Environment, Agricultural Sciences and Spatial Planning (FORMAS) (grant number 942 2015-1128 to MK), Centre for Biological Control (CBC), and Austrian Science Fund FWF (www.fwf.ac.at, grant number 11249 to CPK) are acknowledged.

\section{Availability of data and materials}

All data generated or analyzed during this study are included in this published article [and its Additional files 1 and 2].

\section{Authors' contributions}

$L A$, MD and MaG carried out the experiments. LA and MK conceived and designed the study, carried out the data analysis, interpretation, and discussion, and wrote the manuscript with comments from MS, CPK and DFJ. MiG performed the protein homology modeling and interpretation of data and $C L$ carried out HPAEC-PAD. All authors read and approved the final manuscript.

\section{Ethics approval and consent to participate}

Not applicable

\section{Consent for publication}

Not applicable

\section{Competing interests}

The authors declare that they have no competing interests.

\section{Publisher's Note}

Springer Nature remains neutral with regard to jurisdictional claims in published maps and institutional affiliations.

\section{Author details}

${ }^{1}$ Forest Mycology and Plant Pathology, Swedish University of Agricultural Sciences, P.O. Box 7026, SE-75007 Uppsala, Sweden. ${ }^{2}$ Research division of Biochemical Technology, Institute of Chemical, Environmental and Biological Engineering, Vienna University of Technology, Gumpendorferstrasse 1a, 1060 Vienna, Austria. ${ }^{3}$ Molecular Sciences, Swedish University of Agricultural Sciences, P.O. Box 7015, SE-75007 Uppsala, Sweden. ${ }^{4}$ Institute of Food Technology, University of Natural Resources and Life Sciences, Muthgasse 11, 1190 Vienna, Austria. ${ }^{5}$ Present address: Steinschötelgasse 7, 1100, Vienna, Austria.

Received: 12 December 2017 Accepted: 10 October 2018

Published online: 07 November 2018

\section{References}

1. Willats WG, McCartney L, Mackie W, Knox JP. Pectin: cell biology and prospects for functional analysis. Plant Mol Biol. 2001;47:9-27.

2. Mohnen D. Pectin structure and biosynthesis. Curr Opin Plant Biol. 2008;11: 266-77. https://doi.org/10.1016/j.pbi.2008.03.006.

3. O'Neill MA, Ishii $T$, Albersheim P, Darvill AG. Rhamnogalacturonan II: structure and function of a borate cross-linked cell wall pectic polysaccharide. Annu Rev Plant Biol. 2004;55:109-39. https://doi.org/10. 1146/annurev.arplant.55.031903.141750.

4. Buchanan BB, Gruissem W, Jones RL, editors. Biochemistry \& Molecular Biology of Plants. Rockville: American Society of Plant Physiologists; 2000.

5. Müller-Maatsch J, Bencivenni M, Caligiani A, Tedeschi T, Bruggeman G, Bosch $\mathrm{M}$, et al. Pectin content and composition from different food waste streams. Food Chem. 2016;201:37-45. https://doi.org/10.1016/j. foodchem.2016.01.012.

6. Lombard V, Bernard T, Rancurel C, Brumer H, Coutinho PM, Henrissat B. A hierarchical classification of polysaccharide lyases for glycogenomics. Biochem J. 2010;432:437-44 [PMID: 20925655].

7. Lombard V, Golaconda Ramulu H, Drula E, Coutinho PM, Henrissat B. The carbohydrate-active enzymes database (CAZy) in 2013. Nucleic Acids Res. 2014:42:D490-5. https://doi.org/10.1093/nar/gkt1178.

8. Kubicek CP. Fungi and Lignocellulosic Biomass: Kubicek/Fungi and Lignocellulosic Biomass. Wiley-Blackwell: Oxford; 2012. https://doi.org/10. 1002/9781118414514.

9. Pedrolli DB, Monteiro AC, Gomes E, Carmona EC. Pectin and pectinases: production, characterization and industrial application of microbial Pectinolytic enzymes. Open Biotechnol J. 2009;3:9-18. https://doi.org/10. 2174/1874070700903010009.

10. Mayans O, Scott M, Connerton I, Gravesen T, Benen J, Visser J, et al. Two crystal structures of pectin lyase A from Aspergillus reveal a $\mathrm{pH}$ driven conformational change and striking divergence in the substrate-binding clefts of pectin and pectate lyases. Struct Lond Engl. 1997:5:677-89.

11. Herron SR, Jurnak F. Mechanistic Lessons from Structural Studies of the Pectate Lyases. In: Voragen F, Schols H, Visser R, editors. Adv. Pectin Pectinase Res. Dordrecht: Springer Netherlands; 2003. p. 221-33. https://doi. org/10.1007/978-94-017-0331-4_17.

12. Collmer A, Ried JL, Mount MS. Assay methods for pectic enzymes. Methods Enzymol. 1988;161:329-35. https://doi.org/10.1016/0076-6879(88)61037-8.

13. Kusters-van Someren MA, Harmsen JAM, Kester HCM, Visser J. Structure of the aspergillus Niger pelA gene and its expression in aspergillus Niger and aspergillus nidulans. Curr Genet. 1991;20:293-9. https://doi. org/10.1007/BF00318518.

14. Kusters-van Someren M, Flipphi M, de Graaff $L$, van den Broeck H, Kester $H$, Hinnen A, et al. Characterization of the aspergillus Niger pelB gene: structure and regulation of expression. Mol Gen Genet MGG. 1992;234:113-20.

15. Harmsen JA, Kusters-van Someren MA, Visser J. Cloning and expression of a second aspergillus Niger pectin lyase gene (pelA): indications of a pectin lyase gene family in a. niger. Curr Genet. 1990;18:161-6.

16. Gysler C, Harmsen JA, Kester HC, Visser J, Heim J. Isolation and structure of the pectin lyase D-encoding gene from aspergillus Niger. Gene. 1990;89:101-8.

17. Kitamoto N, Yoshino-Yasuda S, Ohmiya K, Tsukagoshi N. A second pectin lyase gene (pel2) from aspergillus oryzae KBN616: its sequence analysis and 
overexpression, and characterization of the gene products. J Biosci Bioeng 2001;91:378-81.

18. Bazzolli DS, Ribon AOB, de Queiroz MV, de Araújo EF. Molecular characterization and expression profile of pectin-lyase-encoding genes from Penicillium griseoroseum. Can J Microbiol. 2006;52:1070-7. https://doi.org/10.1139/w06-070.

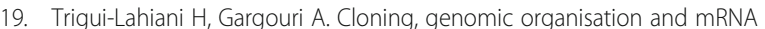
expression of a pectin lyase gene from a mutant strain of Penicillium occitanis. Gene. 2007;388:54-60. https://doi.org/10.1016/j.gene.2006.09.022.

20. Templeton MD, Sharrock KR, Bowen JK, Crowhurst RN, Rikkerink EH. The pectin lyase-encoding gene (pnl) family from Glomerella cingulata: characterization of pnlA and its expression in yeast. Gene. 1994;142:141-6.

21. Wei Y, Shih J, Li J, Goodwin PH. Two pectin lyase genes, pnl-1 and pnl-2, from Colletotrichum gloeosporioides f. sp. malvae differ in a cellulose-binding domain and in their expression during infection of Malva pusilla. Microbiol Read Engl. 2002;148:2149-57. https://doi.org/10.1099/00221287-148-7-2149.

22. Lara-Márquez A, Zavala-Páramo MG, López-Romero E, Calderón-Cortés N, López-Gómez R, Conejo-Saucedo U, et al. Cloning and characterization of a pectin lyase gene from Colletotrichum lindemuthianum and comparative phylogenetic/structural analyses with genes from phytopathogenic and saprophytic/opportunistic microorganisms. BMC Microbiol. 2011;11:260. https://doi.org/10.1186/1471-2180-11-260

23. Shah P, Gutierrez-Sanchez G, Orlando R, Bergmann C. A proteomic study of pectin-degrading enzymes secreted by Botrytis cinerea grown in liquid culture. Proteomics. 2009;9:3126-35. https://doi.org/10.1002/pmic.200800933.

24. Karlsson M, Durling MB, Choi J, Kosawang C, Lackner G, Tzelepis GD, et al. Insights on the evolution of mycoparasitism from the genome of Clonostachys rosea. Genome Biol Evol. 2015;7:465-80. https://doi.org/10. 1093/gbe/evu292.

25. Jensen DF, Knudsen IMB, Lübeck M, Mamarabadi M, Hockenhull J, Jensen B. Development of a biocontrol agent for plant disease control with special emphasis on the near commercial fungal antagonist Clonostachys rosea strain "IK726.". Australas Plant Pathol. 2007;36:95. https://doi.org/10.1071/AP07009.

26. Iqbal M, Dubey M, McEwan K, Menzel U, Franko MA, Viketoft M, et al. Evaluation of Clonostachys rosea for Control of Plant-Parasitic Nematodes in Soil and in Roots of Carrot and Wheat. Phytopathology. 2017. https://doi. org/10.1094/PHYTO-03-17-0091-R.

27. de Vries RP, Jansen J, Aguilar G, Parenicová L, Joosten V, Wülfert F, et al. Expression profiling of pectinolytic genes from aspergillus Niger. FEBS Lett. 2002;530:41-7.

28. Braaksma M, Martens-Uzunova ES, Punt PJ, Schaap PJ. An inventory of the aspergillus Niger secretome by combining in silico predictions with shotgun proteomics data. BMC Genomics. 2010;11:584. https://doi.org/10, 1186/1471-2164-11-584.

29. Tang Q, Liu Y-P, Ren Z-G, Yan X-X, Zhang L-Q. 1.37 A crystal structure of pathogenic factor pectate lyase from Acidovorax citrulli: the structure of pathogenic factor AcPel. Prot Struct Funct Bioinforma. 2013;81:1485-90. https://doi.org/10.1002/prot.24298.

30. Mathelier A, Fornes O, Arenillas DJ, Chen C-Y, Denay G, Lee J, et al. JASPAR 2016: a major expansion and update of the open-access database of transcription factor binding profiles. Nucleic Acids Res. 2016;44:D110-5. https://doi.org/10.1093/nar/gkv1176.

31. Parenicová L, Benen JA, Kester HC, Visser J. pgaA and pgaB encode two constitutively expressed endopolygalacturonases of Aspergillus niger. Biochem J. 2000;345(Pt 3):637-44.

32. Martens-Uzunova ES, Zandleven JS, Benen JAE, Awad H, Kools HJ, Beldman $G$, et al. A new group of exo-acting family 28 glycoside hydrolases of aspergillus Niger that are involved in pectin degradation. Biochem J. 2006; 400:43-52. https://doi.org/10.1042/BJ20060703.

33. Dubey MK, Jensen DF, Karlsson M. Hydrophobins are required for conidial hydrophobicity and plant root colonization in the fungal biocontrol agent Clonostachys rosea. BMC Microbiol. 2014;14:18. https://doi.org/10.1186/ 1471-2180-14-18.

34. Dubey M, Jensen DF, Karlsson M. The ABC transporter ABCG29 is involved in $\mathrm{H} 2 \mathrm{O} 2$ tolerance and biocontrol traits in the fungus Clonostachys rosea. Mol Genet Genomics. 2016;291:677-86. https://doi.org/10.1007/s00438-015-1139-y.

35. Martinez D, Berka RM, Henrissat B, Saloheimo M, Arvas M, Baker SE, et al. Genome sequencing and analysis of the biomass-degrading fungus Trichoderma reesei (syn. Hypocrea jecorina). Nat Biotechnol. 2008;26:553-60. https://doi.org/10.1038/nbt1403.

36. Kubicek CP, Herrera-Estrella A, Seidl-Seiboth V, Martinez DA, Druzhinina IS, Thon $\mathrm{M}$, et al. Comparative genome sequence analysis underscores mycoparasitism as the ancestral life style of Trichoderma. Genome Biol. 2011:12:R40. https://doi.org/10.1186/gb-2011-12-4-r40.

37. Xie B-B, Qin Q-L, Shi M, Chen L-L, Shu Y-L, Luo Y, et al. Comparative genomics provide insights into evolution of trichoderma nutrition style. Genome Biol Evol. 2014;6:379-90. https://doi.org/10.1093/gbe/evu018.

38. Karlsson M, Atanasova L, Jensen DF, Zeilinger S. Necrotrophic Mycoparasites and their genomes. Microbiol Spectr. 2017;5. https://doi.org/10.1128/ microbiolspec.FUNK-0016-2016.

39. Wijesundera RLC, Bailey JA, Byrde RWW. Production of pectin Lyase by Colletotrichum lindemuthianum in culture and in infected bean (Phaseolus vulgaris) tissue. Microbiology. 1984;130:285-90. https://doi.org/10.1099/00221287-130-2-285.

40. Yakoby N, Beno-Moualem D, Keen NT, Dinoor A, Pines O, Prusky D. Colletotrichum gloeosporioides pelB is an important virulence factor in avocado fruit-fungus interaction. Mol Plant Microbe Interact. 2001;14:98895. https://doi.org/10.1094/MPMI.2001.14.8.988.

41. Di Pietro A, Roncero MI. Cloning, expression, and role in pathogenicity of pg1 encoding the major extracellular endopolygalacturonase of the vascular wilt pathogen fusarium oxysporum. Mol Plant Microbe Interact. 1998;11:91-8. https://doi.org/10.1094/MPMI.1998.11.2.91.

42. Saraiva RM, Czymmek KJ, Borges ÁV, Caires NP, Maffia LA. Confocal microscopy study to understand Clonostachys rosea and Botrytis cinerea interactions in tomato plants. Biocontrol Sci Tech. 2015;25:56-71. https://doi. org/10.1080/09583157.2014.948382.

43. Yu H, Sutton JC. Morphological development and interactions of Gliocladium roseum and Botrytis cinerea in raspberry. Can J Plant Pathol. 1997;19:237-46. https://doi.org/10.1080/07060669709500518.

44. Roberti R, Veronesi A, Cesari A, Cascone A, Di Berardino I, Bertini L, et al. Induction of PR proteins and resistance by the biocontrol agent Clonostachys rosea in wheat plants infected with fusarium culmorum. Plant Sci. 2008;175:339-47. https://doi.org/10.1016/j. plantsci.2008.05.003.

45. Mouekouba LDO, Zhang L, Guan X, Chen X, Chen H, Zhang J, et al. Analysis of Clonostachys rosea-induced resistance to tomato gray Mold disease in tomato leaves. PLoS One. 2014;9:e102690. https://doi.org/10.1371/journal.pone.0102690.

46. Lübeck M, Knudsen IMB, Jensen B, Thrane U, Janvier C, Jensen DF. GUS and GFP transformation of the biocontrol strain Clonostachys rosea IK726 and the use of these marker genes in ecological studies. Mycol Res. 2002;106: 815-26. https://doi.org/10.1017/S095375620200607X.

47. Zou C-G, Tu H-H, Liu X-Y, Tao N, Zhang K-Q. PacC in the nematophagous fungus Clonostachys rosea controls virulence to nematodes. Environ Microbiol. 2010;12:1868-77. https://doi.org/10.1111/j. 1462-2920.2010.02191.x.

48. Zou C-G, Tao N, Liu W-J, Yang J-K, Huang X-W, Liu X-Y, et al. Regulation of subtilisin-like protease prC expression by nematode cuticle in the nematophagous fungus Clonostachys rosea. Environ Microbiol. 2010;12: 3243-52. https://doi.org/10.1111/1.1462-2920.2010.02296.x.

49. Van Damme EJM, Culerrier R, Barre A, Alvarez R, Rougé P, Peumans WJ. A novel family of lectins evolutionarily related to class $V$ chitinases: an example of neofunctionalization in legumes. Plant Physiol. 2007;144:662-72. https://doi.org/10.1104/pp.106.087981.

50. Kim YS, Lee JH, Yoon GM, Cho HS, Park SW, Suh MC, et al. CHRK1, a chitinaserelated receptor-like kinase in tobacco. Plant Physiol. 2000;123:905-15.

51. Hennig M, Jansonius JN, Terwisscha van Scheltinga AC, Dijkstra BW, Schlesier B. Crystal structure of concanavalin B at 1.65 a resolution. An "inactivated" chitinase from seeds of Canavalia ensiformis. J Mol Biol. 1995; 254:237-46. https://doi.org/10.1006/jmbi.1995.0614.

52. Yoder M, Keen N, Jurnak F. New domain motif: the structure of pectate lyase C, a secreted plant virulence factor. Science. 1993;260:1503-7. https:// doi.org/10.1126/science.8502994.

53. Lietzke SE, Yoder MD, Keen NT, Jurnak F. The three-dimensional structure of pectate Lyase $\mathrm{E}$, a plant virulence factor from Erwinia chrysanthemi. Plant Physiol. 1994;106:849-62.

54. Pickersgill R, Smith D, Worboys K, Jenkins J. Crystal structure of Polygalacturonase from Erwinia carotovora ssp. carotovora. J Biol Chem. 1998;273:24660-4. https://doi.org/10.1074/jbc.273.38.24660.

55. Vitali J, Schick B, Kester HCM, Visser J, Jurnak F. The three-dimensional structure of Aspergillus niger pectin Lyase B at 1.7-Å resolution. Plant Physiol. 1998;116:69-80. https://doi.org/10.1104/pp.116.1.69.

56. Marchler-Bauer A, Derbyshire MK, Gonzales NR, Lu S, Chitsaz F, Geer LY, et al. CDD: NCBI's conserved domain database. Nucleic Acids Res. 2015;43: D222-6. https://doi.org/10.1093/nar/gku1221. 
57. Finn RD, Attwood TK, Babbitt PC, Bateman A, Bork P, Bridge AJ, et al. InterPro in 2017-beyond protein family and domain annotations. Nucleic Acids Res. 2017;45:D190-9. https://doi.org/10.1093/nar/gkw1107.

58. de Castro E, Sigrist CJA, Gattiker A, Bulliard V, Langendijk-Genevaux PS, Gasteiger E, et al. ScanProsite: detection of PROSITE signature matches and ProRule-associated functional and structural residues in proteins. Nucleic Acids Res. 2006;34:W362-5. https://doi.org/10.1093/nar/gkl124.

59. Sievers F, Wilm A, Dineen D, Gibson TJ, Karplus K, Li W, et al. Fast, scalable generation of high-quality protein multiple sequence alignments using Clustal omega. Mol Syst Biol. 2014;7:539. https://doi.org/10.1038/msb.2011.75.

60. Edgar RC. MUSCLE: multiple sequence alignment with high accuracy and high throughput. Nucleic Acids Res. 2004;32:1792-7. https://doi.org/10.1093/ nar/gkh340.

61. Ronquist F, Teslenko M, van der Mark P, Ayres DL, Darling A, Höhna S, et al. MrBayes 3.2: efficient Bayesian phylogenetic inference and model choice across a large model space. Syst Biol. 2012;61:539-42. https://doi.org/10. 1093/sysbio/sys029.

62. Lee T-S. Reverse Conservation Analysis Reveals the Specificity Determining Residues of Cytochrome P450 Family 2 (CYP 2). Evol Bioinform. 2008:4. https://doi.org/10.4137/EBO.S291.

63. Mayrose I, Graur D, Ben-Tal N, Pupko T. Comparison of site-specific rateinference methods for protein sequences: empirical Bayesian methods are superior. Mol Biol Evol. 2004;21:1781-91. https://doi.org/10.1093/ molbev/msh194.

64. Pupko T, Bell RE, Mayrose I, Glaser F, Ben-Tal N. Rate4Site: an algorithmic tool for the identification of functional regions in proteins by surface mapping of evolutionary determinants within their homologues. Bioinforma Oxf Engl. 2002;18(Suppl 1):S71-7.

65. Yang J, Yan R, Roy A, Xu D, Poisson J, Zhang Y. The I-TASSER suite: protein structure and function prediction. Nat Methods. 2015;12:7-8. https://doi.org/ 10.1038/nmeth.3213.

66. Seyedarabi A, To T, Ali S, Hussain S, Fries M, Madsen R, et al. Structural insights into substrate specificity and the anti $\beta$-elimination mechanism of pectate Lyase. Biochemistry (Mosc). 2010;49:539-46. https://doi.org/10.1021/ bi901503g.

67. Utermark J, Karlovsky P. Genetic transformation of filamentous fungi by agrobacterium tumefaciens. Protoc Exch. 2008. https://doi.org/10.1038/ nprot.2008.83.

68. Nygren CMR, Eberhardt U, Karlsson M, Parrent JL, Lindahl BD, Taylor AFS. Growth on nitrate and occurrence of nitrate reductase-encoding genes in a phylogenetically diverse range of ectomycorrhizal fungi. New Phytol. 2008; 180:875-89. https://doi.org/10.1111/j.1469-8137.2008.02618.x.

69. Linger JG, Taylor LE, Baker JO, Vander Wall T, Hobdey SE, Podkaminer K, et al. A constitutive expression system for glycosyl hydrolase family 7 cellobiohydrolases in Hypocrea jecorina. Biotechnol Biofuels. 2015;8. https:// doi.org/10.1186/s13068-015-0230-2.

70. Atanasova L, Druzhinina IS. Global nutrient profiling by phenotype MicroArrays: a tool complementing genomic and proteomic studies in conidial fungi. J Zhejiang Univ Sci B. 2010;11:151-68. https://doi.org/10. 1631/jzus.B1000007.

71. Dubey MK, Broberg A, Sooriyaarachchi S, Ubhayasekera W, Jensen DF, Karlsson M. The glyoxylate cycle is involved in pleotropic phenotypes, antagonism and induction of plant defence responses in the fungal biocontrol agent Trichoderma atroviride. Fungal Genet Biol. 2013;58-59:3341. https://doi.org/10.1016/j.fgb.2013.06.008.

72. Tzelepis G, Dubey M, Jensen DF, Karlsson M. Identifying glycoside hydrolase family 18 genes in the mycoparasitic fungal species Clonostachys rosea. Microbiol Read Engl. 2015;161:1407-19. https://doi.org/10.1099/mic.0.000096.

73. Kamou NN, Dubey M, Tzelepis G, Menexes G, Papadakis EN, Karlsson M, et al. Investigating the compatibility of the biocontrol agent Clonostachys rosea IK726 with prodigiosin-producing Serratia rubidaea S55 and phenazine-producing Pseudomonas chlororaphis ToZa7. Arch Microbiol. 2016;198:369-77. https://doi.org/10.1007/s00203-016-1198-4.

74. Pfaffl MW. A new mathematical model for relative quantification in real-time RT-PCR. Nucleic Acids Res. 2001;29:e45.

75. Xiao G, Ying S-H, Zheng P, Wang Z-L, Zhang S, Xie X-Q, et al. Genomic perspectives on the evolution of fungal entomopathogenicity in Beauveria bassiana. Sci Rep. 2012;2. https://doi.org/10.1038/srep00483.

76. Cuomo CA, Untereiner WA, Ma L-J, Grabherr M, Birren BW. Draft genome sequence of the cellulolytic fungus Chaetomium globosum. Genome Announc. 2015;3. https://doi.org/10.1128/genomeA.00021-15.
77. Baroncelli R, Sreenivasaprasad S, Sukno SA, Thon MR, Holub E. Draft genome sequence of Colletotrichum acutatum Sensu Lato (Colletotrichum fioriniae). Genome Announc. 2014;2. https://doi.org/10. 1128/genomeA.00112-14.

78. O'Connell RJ, Thon MR, Hacquard S, Amyotte SG, Kleemann J, Torres MF, et al. Lifestyle transitions in plant pathogenic Colletotrichum fungi deciphered by genome and transcriptome analyses. Nat Genet. 2012;44: 1060-5. https://doi.org/10.1038/ng.2372.

79. Zampounis A, Pigné S, Dallery J-F, Wittenberg AHJ, Zhou S, Schwartz DC, et al. Genome sequence and annotation of Colletotrichum higginsianum, a causal agent of crucifer anthracnose disease. Genome Announc. 2016;4. https://doi.org/10.1128/genomeA.00821-16.

80. Jiménez DJ, Hector RE, Riley R, Lipzen A, Kuo RC, Amirebrahimi M, et al. Draft genome sequence of Coniochaeta ligniaria NRRL 30616, a Lignocellulolytic fungus for bioabatement of inhibitors in plant biomass hydrolysates. Genome Announc. 2017;5. https://doi.org/10.1128/genomeA.01476-16.

81. Zheng P, Xia Y, Xiao G, Xiong C, Hu X, Zhang S, et al. Genome sequence of the insect pathogenic fungus Cordyceps militaris, a valued traditional Chinese medicine. Genome Biol. 2011;12:R116. https://doi.org/ 10.1186/gb-2011-12-11-r116

82. Wu W, Davis RW, Tran-Gyamfi MB, Kuo A, LaButti K, Mihaltcheva S, et al. Characterization of four endophytic fungi as potential consolidated bioprocessing hosts for conversion of lignocellulose into advanced biofuels. Appl Microbiol Biotechnol. 2017;101:2603-18. https://doi.org/10.1007/ s00253-017-8091-1.

83. Blanco-Ulate B, Rolshausen PE, Cantu D. Draft genome sequence of the grapevine dieback fungus Eutypa lata UCR-EL1. Genome Announc. 2013;1. https://doi.org/10.1128/genomeA.00228-13.

84. Wiemann P, Sieber CMK, von Bargen KW, Studt L, Niehaus E-M, Espino JJ, et al. Deciphering the cryptic genome: genome-wide analyses of the rice pathogen fusarium fujikuroi reveal complex regulation of secondary metabolism and novel metabolites. PLoS Pathog. 2013;9:e1003475. https:// doi.org/10.1371/journal.ppat.1003475.

85. Cuomo CA, Güldener U, Xu J-R, Trail F, Turgeon BG, Di Pietro A, et al. The fusarium graminearum genome reveals a link between localized polymorphism and pathogen specialization. Science. 2007;317:1400-2. https://doi.org/10.1126/science.1143708.

86. Ma L-J, van der Does HC, Borkovich KA, Coleman JJ, Daboussi M-J, Di Pietro A, et al. Comparative genomics reveals mobile pathogenicity chromosomes in fusarium. Nature. 2010:464:367-73. https://doi.org/10.1038/nature08850.

87. Coleman JJ, Rounsley SD, Rodriguez-Carres M, Kuo A, Wasmann CC, Grimwood J, et al. The genome of Nectria haematococca: contribution of supernumerary chromosomes to gene expansion. PLoS Genet. 2009;5: e1000618. https://doi.org/10.1371/journal.pgen.1000618.

88. DiGuistini S, Wang Y, Liao NY, Taylor G, Tanguay P, Feau N, et al. Genome and transcriptome analyses of the mountain pine beetle-fungal symbiont Grosmannia clavigera, a lodgepole pine pathogen. Proc Natl Acad Sci U S A. 2011;108:2504-9. https://doi.org/10.1073/pnas.1011289108.

89. Dean RA, Talbot NJ, Ebbole DJ, Farman ML, Mitchell TK, Orbach MJ, et al. The genome sequence of the rice blast fungus Magnaporthe grisea. Nature. 2005;434:980-6. https://doi.org/10.1038/nature03449.

90. Gao Q, Jin K, Ying S-H, Zhang Y, Xiao G, Shang Y, et al. Genome sequencing and comparative transcriptomics of the model entomopathogenic fung Metarhizium anisopliae and M acridum. PLoS Genet. 2011;7:e1001264. https://doi.org/10.1371/journal.pgen.1001264.

91. Berka RM, Grigoriev IV, Otillar R, Salamov A, Grimwood J, Reid I, et al. Comparative genomic analysis of the thermophilic biomass-degrading fungi Myceliophthora thermophila and Thielavia terrestris. Nat Biotechnol. 2011; 29:922-7. https://doi.org/10.1038/nbt.1976.

92. Baker SE, Schackwitz W, Lipzen A, Martin J, Haridas S, LaButti K, et al. Draft genome sequence of Neurospora crassa strain FGSC 73. Genome Announc. 2015;3. https://doi.org/10.1128/genomeA.00074-15.

93. Galagan JE, Calvo SE, Borkovich KA, Selker EU, Read ND, Jaffe D, et al. The genome sequence of the filamentous fungus Neurospora crassa. Nature. 2003:422:859-68. https://doi.org/10.1038/nature01554.

94. Gladieux P, Wilson BA, Perraudeau F, Montoya LA, Kowbel D, Hann-Soden C, et al. Genomic sequencing reveals historical, demographic and selective factors associated with the diversification of the fire-associated fungus Neurospora discreta. Mol Ecol. 2015;24:5657-75. https://doi.org/10.1111/mec.13417.

95. Ellison CE, Stajich JE, Jacobson DJ, Natvig DO, Lapidus A, Foster B, et al. Massive changes in genome architecture accompany the transition to self- 
fertility in the filamentous fungus Neurospora tetrasperma. Genetics. 2011; 189:55-69. https://doi.org/10.1534/genetics.111.130690.

96. Haridas S, Wang Y, Lim L, Massoumi Alamouti S, Jackman S, Docking R, et al. The genome and transcriptome of the pine saprophyte Ophiostoma piceae, and a comparison with the bark beetle-associated pine pathogen Grosmannia clavigera. BMC Genomics. 2013;14:373. https://doi.org/10.1186/ 1471-2164-14-373.

97. Espagne E, Lespinet O, Malagnac F, Da Silva C, Jaillon O, Porcel BM, et al. The genome sequence of the model ascomycete fungus Podospora anserina. Genome Biol. 2008;9:R77. https://doi.org/10.1186/gb-2008-9-5-r77.

98. Druzhinina IS, Chenthamara K, Zhang J, Atanasova L, Yang D, Miao Y, et al. Massive lateral transfer of genes encoding plant cell walldegrading enzymes to the mycoparasitic fungus Trichoderma from its plant-associated hosts. PLoS Genet. 2018;14:e1007322. https://doi.org/10. 1371/journal.pgen.1007322.

99. Klosterman SJ, Subbarao KV, Kang S, Veronese P, Gold SE, Thomma BPHJ, et al. Comparative genomics yields insights into niche adaptation of plant vascular wilt pathogens. PLoS Pathog. 2011;7:e1002137. https://doi.org/10. 1371/journal.ppat.1002137.

100. Staats M, van Kan JAL. Genome update of Botrytis cinerea strains B05.10 and T4. Eukaryot Cell. 2012;11:1413-4. https://doi.org/10.1128/EC.00164-12.

101. Amselem J, Cuomo CA, van Kan JAL, Viaud M, Benito EP, Couloux A, et al. Genomic analysis of the necrotrophic fungal pathogens Sclerotinia sclerotiorum and Botrytis cinerea. PLoS Genet. 2011;7:e1002230. https://doi. org/10.1371/journal.pgen.1002230.

Ready to submit your research? Choose BMC and benefit from:

- fast, convenient online submission

- thorough peer review by experienced researchers in your field

- rapid publication on acceptance

- support for research data, including large and complex data types

- gold Open Access which fosters wider collaboration and increased citations

- maximum visibility for your research: over $100 \mathrm{M}$ website views per year

At $\mathrm{BMC}$, research is always in progress.

Learn more biomedcentral.com/submissions 